INTER NATIONAL MONETARY FUND

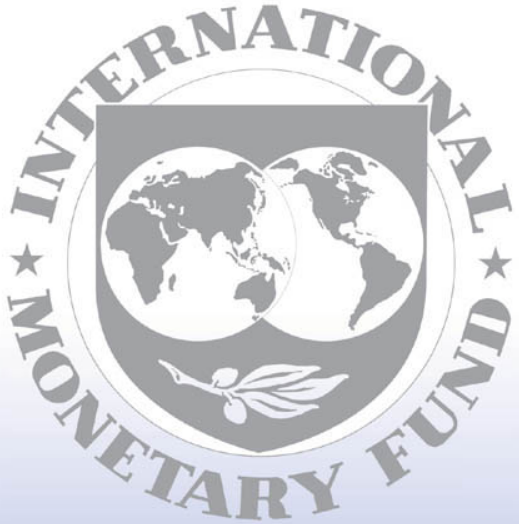

Staff

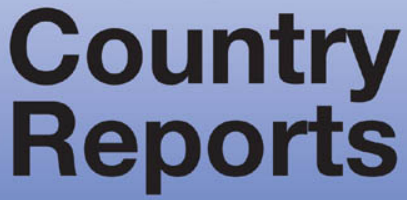




\section{Republic of Palau: Recent Economic Developments}

This Recent Economic Developments paper for the Republic of Palau was prepared by a staff team of the International Monetary Fund as background documentation for the periodic consultation with the member country. It is based on the information available at the time it was completed on November 30, 2001. The views expressed in this document are those of the staff team and do not necessarily reflect the views of the government of the Republic of Palau or the Executive Board of the IMF.

The policy of publication of staff reports and other documents by the IMF allows for the deletion of market-sensitive information.

To assist the IMF in evaluating the publication policy, reader comments are invited and may be sent by e-mail to Publicationpolicy@imf.org.

Copies of this report are available to the public from

International Monetary Fund • Publication Services

$70019^{\text {th }}$ Street, N.W. - Washington, D.C. 20431

Telephone: (202) 623-7430 - Telefax: (202) 623-7201

E-mail: publications@imf.org Internet: http://www.imf.org

Price: $\$ 15.00$ a copy

\section{International Monetary Fund \\ Washington, D.C.}




\section{INTERNATIONAL MONETARY FUND \\ REPUBLIC OF PALAU \\ Recent Economic Developments}

Prepared by Wafa Fahmi Abdelati, Yougest Khatri, and Jung Yeon Kim (all APD)

Approved by the Asia and Pacific Department

November 30,2001

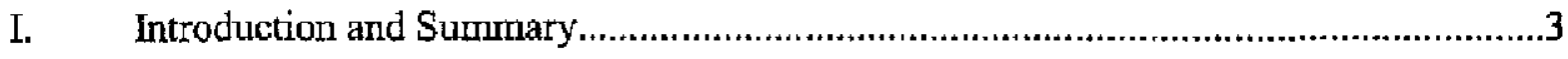

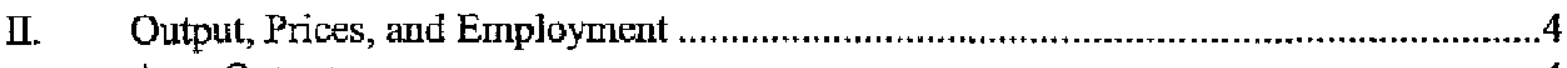

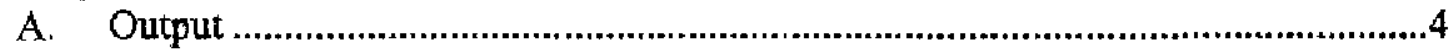

B. Prices, Employment, and Wages.............................................................6

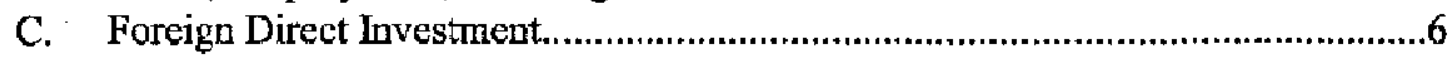

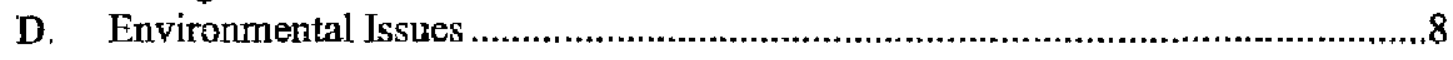

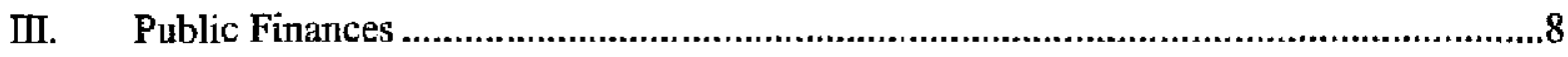

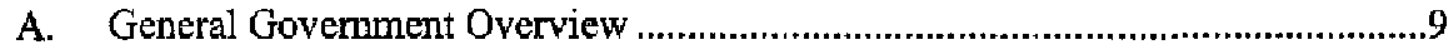

B. State Governments ...................................................................................

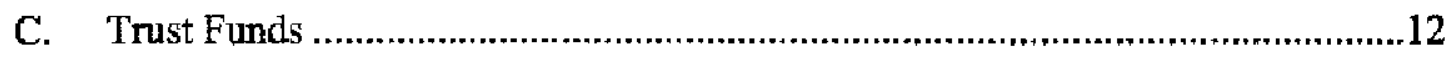

D. Performance of Nonfinancial Public Enterprises.............................................14

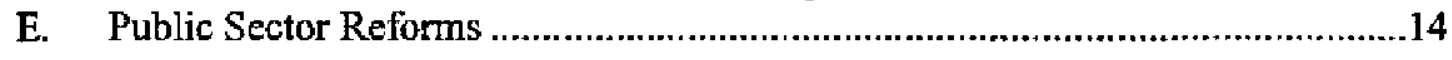

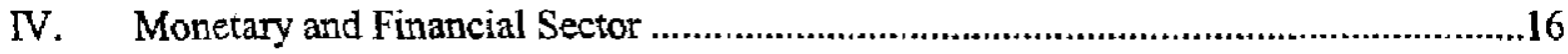

A. Commercial Banks.................................................................................16

B. $\quad$ National Development Bank of Palau.........................................................17

C. Regulatory and Supervisory Framework........................................................17

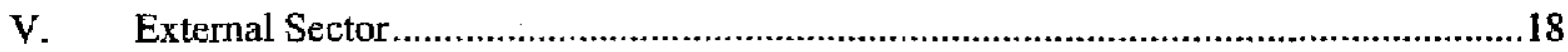

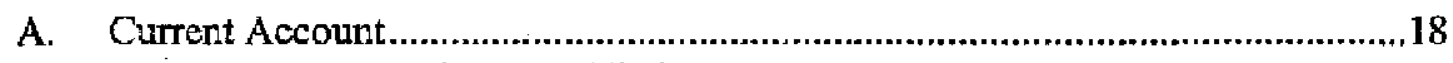

B. Capital Account and External Debt ..............................................................20

C. Exchange and Trade System ...............................................................................21

$\underline{\text { Tables }}$

1. Selected Economic and Financial Indicators, 1993/94-2000/01 .............................22

2. Balance of Payments, 1994/95-2000/01 …......................................................23

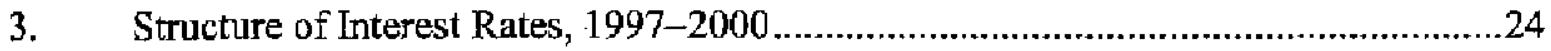

4. Gross Domestic Product, 1995-2001 …........................................................25

5. Visitor Arrivals by Purpose and by Country of Residency, 1996-2001 .....................26 
6. Employed Persons by Industry, 1990, 1995, 1999, and 2000 .......................27

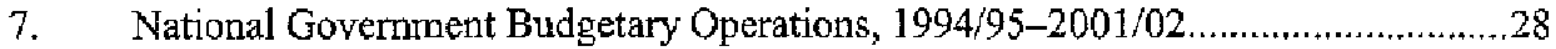

8. U.S. Grants, 1994/95-2008/09 ................................................................29

9. National Govemment Expenditure by Budget Category, 1994/95-1999/00 _...........30

10. Operating Accounts of the State Governments, 1992/93-1998/99 ....................31

11. Financial Position of the Compact Section 211(f) Trust Fund, 1994/95-2000/01 _...32

12. Financial Position of the Social Security Fund, 1993/94-2000/01 ...................33

13. Financial Position of the Civil Service Pension Fund, 1992/93 2000/01 ................34

14. Operating Accounts of the Major Public Corporations 1994/95-1999/00 .............35

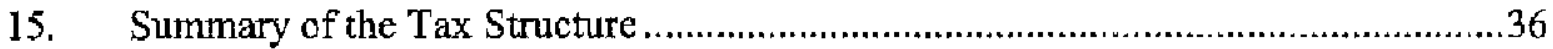

16. Operating Accounts of the National Development

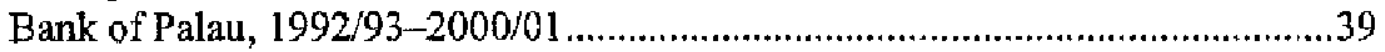

17. Assets and Liabilities of the National Development

Bank of Palau, 1993/94-2000/01 .........................................................40

18. Credit Allocation by the National Development Bank of Palau, 1993-2001 .........41

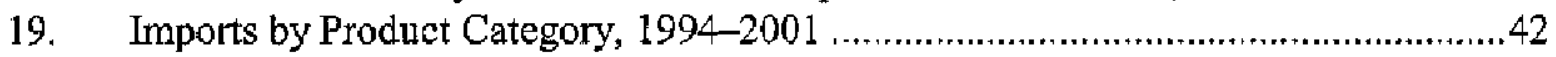

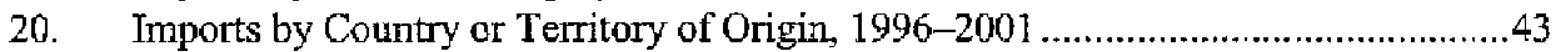

21. National Government Debt and Debt Service, 1992/93-2000/01 ....................44

22. Financial Holdings of the Central Government, 1992/93-2000/01 ..................45

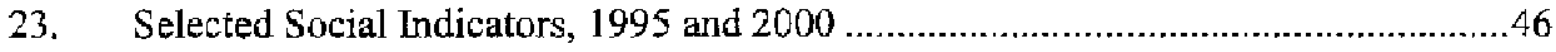




\section{INTRODUCTION AND SUMMARY}

1. The Republic of Palau (hereafter Palau), located in the Western Pacific, is among the smallest of the Pacific islands and has a relatively high per capita GDP. ${ }^{1}$ The population is around 19,000 , and per capita GDP is estimated at $\$ 6,000$ in 2000 . Palau consists of eight main islands and some 250 smaller islands making up an archipelago that stretches over $650 \mathrm{~km}$. The islands were part of a strategic trust of the United Nations, administered by the U.S. from 1947, and became self-governing in 1981 and independent in 1994, since then Palau has been in free association with the U.S. (Staff Report, Box 1). ${ }^{2}$ Under the Compact of Free Association (Compact), Palau receives about $\$ 600$ million over 15 years to 2008/09. Palau faces many development constraints common among Pacific island economies, including a narrow resource base, geographical isolation, a small domestic market, a lack of infrastructure and skilled labor, and vulnerability to extemal and natural shocks.

2. Palau has made a modest recovery in the last two years. Real GDP growth has been about 1 percent in 2000 and 2001 , after the recession brought about by the Asian crisis reached its trough of negative $5 \frac{1 / 2}{2}$ percent growth in 1999 (Table I). This recovery was mainly due to grant financed large infrastructure projects. However, the outlook on tourism, Palau's major industry, remains weak due to the events on September 11, and the expected E1 Niño, which also threaten the development of tourism-related private sector projects.

3. Palau remains heavily dependent on grants from the United States to finance large fiscal deficits. Compact grants have averaged 16 percent of GDP in the last six years, in addition to 8 percent of GDP in non-Compact U.S. grants and 3 percent of GDP in grants from other countries. The large upfront disbursements of Compact grants provided for an accumulated balance of unspent current and capital grants that form government financia] assets (or reserve assets) a large part of which is tied to specific projects. With a relatively narrow tax base, low tax rates, and high current expenditure (averaging 55 percent of GDP in the last three years), the overall fiscal deficit after grants has averaged 9 percent of GDP in the last seven years, financed by grants and asset drawdown. ${ }^{3}$ Recognizing the need to generate domestic funds to replace the imminent loss of Compact grants, the new administration that took office in January 2001 is implementing tax and expenditure reforms.

${ }^{1}$ Out of 14 Pacific island countries (PICs), Palau is the fourth smallest in terms of population and has the second highest per capita GDP. Ten of the fourteen PICs are Fund members.

2 Independence was achieved only after a number of hard fought referenda on the ratification of the Compact of Free Association - the main sticking point was whether Palau would be allowed to have nuclear-free status.

${ }^{3}$ The deficits excluding grants have averaged 34 percent of GDP in the last seven years. 
4. With the decline in tourist receipts, the external current account has recorded large deficits in recent years. Imports increased to accommodate the large infrastructure projects, and the export base remained narrow (tuna fish and garment exports). After benefiting from a period of bullish U.S. stock markets, investment income declined by 17 percent in $2000 / 01$. Reserve assets have been temporarily boosted by $\$ 30$ million in capital inflows from Taiwan Province of China to finance public infrastructure (Table 2).

5. Banking operations appear sound as the larger banks are subject to U.S. regulations and nonperforming loans are reported to be very low. However, banking data is sparse and there is no supervisory framework in place. Banks appear to benefit from large interest rate spreads and very cautious lending practices (Table 3). Financial problems of the development bank resulted in a sharp reduction in lending, but this was reversed in 2000 following restructuring measures and a budgetary transfer. In June 2001, congress approved financial sector legislation that limits the scope for money laundering and provides a framework for banking regulation and supervision. A financial institutions commission is being set up to implement the new legislation.

\section{OutPut, Prices, AND Employment}

\section{A. Output}

6. Palau experienced a modest recovery of 1 percent real GDP growth in $\mathbf{2 0 0 0}$ from a recession of negative $5 \% / 2$ percent growth in $19999^{4}$ The economic slowdown, which began in 1997, reached its trough in 1999 with the impact of the Asian crisis on tourism, the phasing down of U.S. grants under the Compact, and freezing of loan activity by the National Development Bank of Palau (NDBP). The rebound in 2000 was mostly driven by large infrastructure projects including the Compact Road (Babeldaob island's ring road), Koror-Babeldaob (K-B) Bridge, and National Capito] which began in late 1999 , totaling over $\$ 160$ million to be spent over four years.

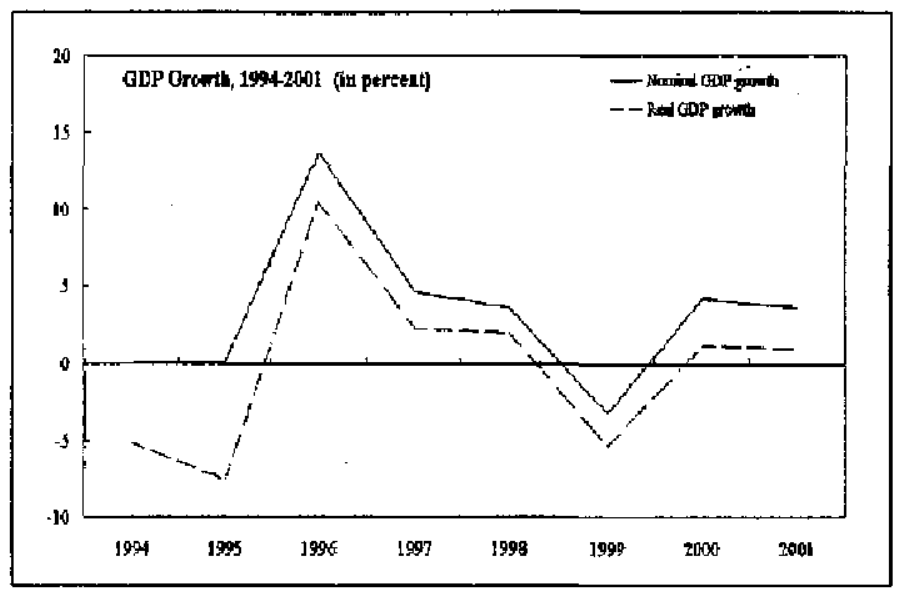

${ }^{4}$ Real GDP estimates are based on nominal GDP data compiled to 1999 and estimates for 2000 and 2001. U.S. deflator is used until 1999 as Palau began compiling its CPI in 2000. See Annex of the Palau-Staff Report for the 2001 Article IV Consultation. 
7. Construction activity led the recovery, financed by higher foreign grants and the resumption of NDBP lending and guarantees. The construction sector recorded a significant improvement of 8 percent in 2000 from negative 21 percent in 1999 (Table 4). As imports of heavy equipment for the new infrastructure projects rose sharply, the trade sector also rebounded from negative 7 percent to 4 percent growth in 1999 . The finance and insurance sector recovered from negative 25 percent to 6 percent growth in 2000 as demand for loans increased. The growth in construction activity, combined with a recovery in the financial sector, had a positive effect on real estate and business services, which grew by 6 percent in 2000 from negative 30 percent in 1999. Transport and communication sectors also contributed to the recovery by sustaining 7 percent growth in 2000 reflecting growth in internet-related and mobile telephone services.

8. Meanwhile, activities in the hotel and restaurant sector remained flat as the number of tourist and business arrivals, which had declined significantly since the Asian crisis, recovered only marginally in 2000 . Agricultural activity, which accounts for only 1 percent of GDP, remained

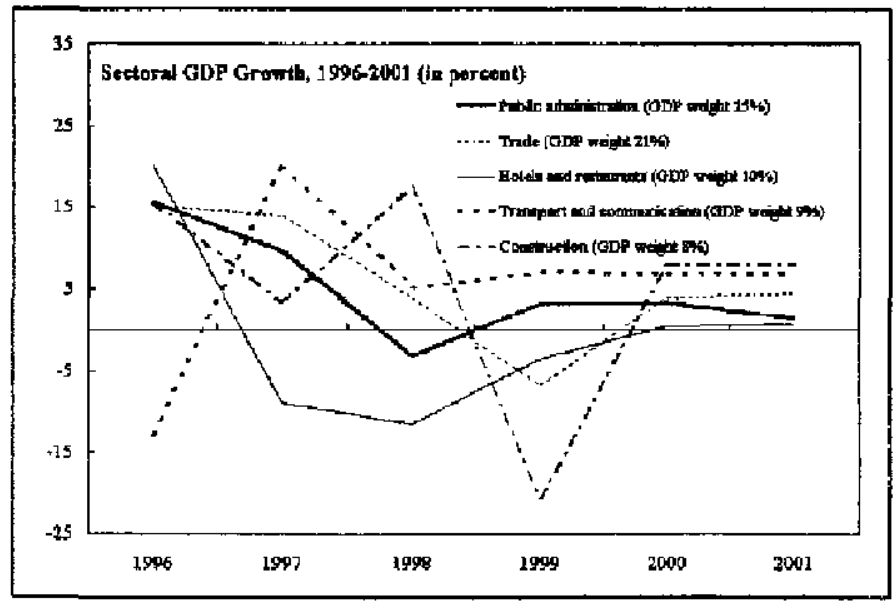
stagnant (Table 5).

9. Economic activity in $\mathbf{2 0 0 1}$ is estimated to have grown by only 1 percent in real terms. Although Palau seems to have stepped out of negative growth, the near-term prospects remain a concem. Most industries are anticipating growth levels similar to those of 2000 , particularly following the events of September 11, 2001. Moreover, the expected El Niño in the spring of 2002 could also affect tourism and slow down the development of private tourism-related projects.

10. Tourism remains the main source of future growth and its prospects depend on infrastructure development and foreign investment. Tourist activity is currently limited to scuba diving and snorkeling, but there is a potential to also provide facilities for golfing, hiking, and sports fishing, especially with the development of Babeldaob, the largest island. Completion of the Compact ring road has been delayed due to rainy weather and unexpected soil conditions. On current plans, the K-B Bridge is expected to open in early 2002 , and the Compact road by the summer of 2004 . Their completion should greatly improve opportunities to expand tourist facilities and related commercial activities. In addition, private sector projects estimated at $\$ 100$ million have received permits and are planned for completion by mid-2003, including botels, golf courses, and ancillary services. 


\section{B. Prices, Employment, and Wages}

11. Palau began compiling quarterly CPI data for Koror from June 2000. The 12month inflation rate to June 2001 was estimated at $2 \% / 4$ percent, lower than for the U.S. The items registering the largest increase during this period were housing ( 7 percent), followed by clothing and footwear ( 4 percent), and food ( 3 percent). Prices of alcohol, tobacco, and betel mut declined slightly by less than $1 / 2$ percent over the 12 -month period.

12. Employment increased by 12 percent in 2000 mainly due to foreign workers in the construction and service sectors. Palauans constitute about 52 percent of the workforce, and more than half of those are government employees. Employment of Palauan nationals remained unchanged in 1999 and increased by 5 percent in 2000 , following the resumption of NDBP lending and pick up in construction. Although the number for non-Palauan workers also remained constant in 1999, it increased by 21 percent in 2000 . Workers from Philippines constitute the largest single country of origin, amounting to over one-half of total foreign workers.

13. As the share of foreign workers in the labor force increased, average wages declined by about 3 percent in 2000. The average wage of Palauans remained stable, but the average wage for non-Palauans declined by about 5 percent. Wages in the construction and service sectors are lower than average. The financial sector had the highest reported average gross wage in 2000 ( $\$ 16,700)$, followed by professional and related services $(\$ 13,300)$, and public

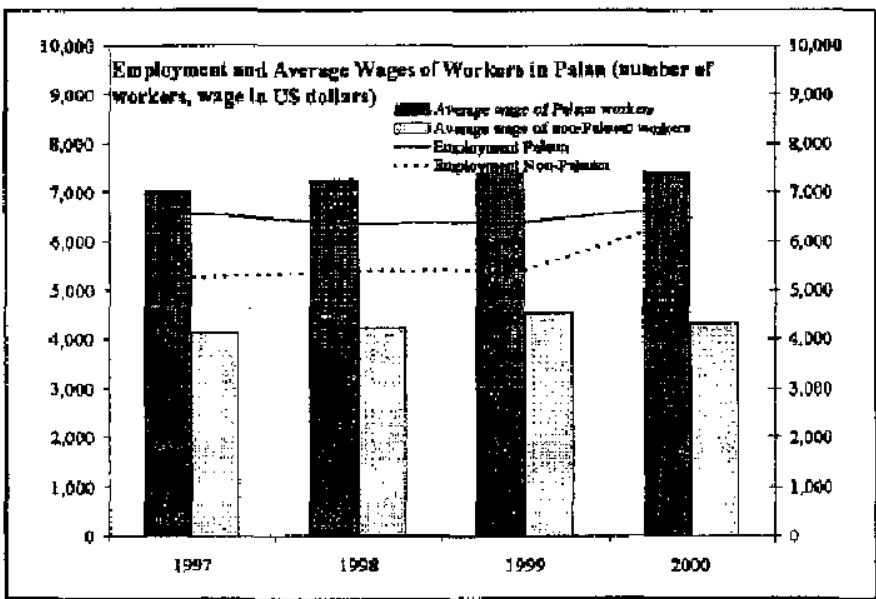
administration $(\$ 11,400$ ) (Table 6). The minimum wage scheme of $\$ 2.50$ per hour for Palauan workers, which was introduced by legislation in early 2001 , may induce a further inflow of foreign workers who are willing to accept much lower hourly wages.

\section{Foreign Direct Investment}

14. A number of procedural obstacles limit foreign investment flows. The main obstacles include cumbersome foreign investment regulations, constraint on land use, labor shortages and regulations on foreign labor, and restrictions on the size of investment income in some sectors. As a result, only 23 Foreign Investment Approval Certificates (FIAC) were issued in 2000, 12 percent lower compared to 1999. Of those, three were for banking businesses; three for construction, engineering, and design; and two were for auditing and accounting services. The rest were for miscellaneous activities including architecture, restaurant, sports facilities, consulting services, health care services, Internet game sites, 
water supply, and wireless communication. In the first nine months of 2001, a total of 14 additional FIACs were issued out of 16 applications.

\section{Foreign investments are regulated by the Foreign Investment Board (FIB),} which was established in $\mathbf{1 9 8 1}$. The FIB is comprised of seven members, many of who are members of the local business community. The application procedures are reported to entail a number of different documents and agencies, which can span several months, and the cumbersome regulations have been criticized as discouraging for the interested investor.

\section{The inability to use land as collateral also acts as a significant barrier to foreign} investment. Foreigners are prohibited from owning land in Palau; instead, they are able to lease land for up to 50 years. However, even leasing can be a problem as land-ownership rights are poorly defined due to the historically communal form of ownership. The authorities expanded the Land Courts to expedite resolving existing court claims. However, it has been difficult for the Land Courts to resolve cases expeditiously. Out of a total of 8,540 cases recorded in 1989 , only about 50 percent of all cases have been settled to date.

\section{Labor laws can also act to deter foreign investment. The current foreign} investment regulations stipulate the share of local employment for a number of activities, and those nationals must be paid the minimum wage of $\$ 2.50$ per hour. When hiring non-Palauan workers, foreign investors must pay an annual fee of $\$ 500$ per head, but this does not apply if the foreign workers are hired by Pafauan investors. Foreign workers must contribute to social security, regardless of the length of their contract and their eligibility to receive benefits from the system at a later stage.

18. Some sectors are restricted from foreign participation. These include wholesale and retail trade, alf tour-related businesses, ocean transportation, land transportation, and car rentals. For hotels, foreign investment is only allowed if the number of rooms exceeds 50 .

19. Foreign investors have resorted to ways to circumvent these restrictions. In what has been commonly referred to as a so-called 'front,' the foreign investor provides capital and operates the business as a hired manager by the Palauan. The Palauan front is responsible for signing legal documents, and he/she receives a certain percentage of profits. This practice reduces transparency of business operations and complicates taxation. Moreover, it has been problematic for both the foreign investor and Palauan partners. Some foreign investors have difficulties in finding someone they can trust to act as local front, ant this can discourage larger investments. For the Palauan, they can find themselves liable to large outstanding debts and liabilities once the foreign investor flees the country.

\section{Recognizing the need to remove impediments to foreign investment, a new} foreign investment law is currently under committee review in congress. The proposed law aims to provide a legal systetn that is simple, transparent, and non-diseriminatory. It is also intended that the FIB be abolished and a one-stop foreign investment licensing unit be placed in the Ministry of Commerce. 


\section{Environmental Issues}

21. Palau shares similar concerns to those of other Pacific island countries on global climate changes and storm damage. Climate changes may result in damage to infrastructure and the ecosystem of coastal areas, causing soil erosion, changes in biodiversity, coastal inundation, and extensive coral bleaching. Scientists expect another El Niño and a severe drought in the spring of 2002 in the region. Among other things, this could be expected to reduce the potential flow of income from tourism, although the severity of the impact is difficult to predict.

22. Recognizing Palau's vulnerability to environmental damage, the authorities have accorded this issue the utmost priority. A number of governmental organizations bave recently been established including the Office of Environmental Response and Coordination (OERC), the Palau Conservation Society (PCS), and the Palau Environmental Quality Protection Board (PEQPB). Palau recently acceded to the 1995 Vienna Convention on Protection of the Ozone Layer and the 1987 Montreal Protocol on Substances That Deplete the Ozone Layer. The Ministry of Resources and Development, in coordination with the OERC, hosted a national workshop to review and assess vulnerability to climate and possible adaptation options for Palau. Meanwhile, the Drought Mitigation Committee in Palau has been educating the locals on El Niño and drought, water resources, sanitation and health, drought crops, fire prevention, and public safety. In early 2001, the United Nations recognized Palau's efforts in this area and selected it as one of the countries to be highlighted in the global synergies review process.

\section{Public Finances}

23. The public sector in Palau consists of the national government, 16 state governments, and a number of nonfinancial public enterprises. ${ }^{5}$ The national government is funded through tax revenue, nontax revenue, and foreign grants. ${ }^{6}$ Most public enterprises receive budgetary subsidies, while the noncommercial public enterprises rely on government transfers or direct federal contributions. The state governments receive some government transfers and have their own funding sources.

${ }^{5}$ The executive branch consists of the Office of the President, the Office of the VicePresident, and eight cabinet ministries (Administration, Commerce and Trade, Community and Cultural Affairs, Education, Health, Justice, Resources and Development, and State); the legislative branch consists of two houses, the Senate and the House of Delegates.

${ }^{6}$ Revenue is placed in, and expenditure allocated from, four main funds: (1) the General Fund; (2) the Special Revenue Fund; (3) the Capital Project Fund; and (4) the Debt-Service Fund. 


\section{A. Geueral Government Overview}

24. Budget deficits have averaged 9 percent of GDP (after grants) in the last six years, financed by Compact grant disbursements, about half of which were associated with capital projects, while the remainder was intended to finance current operations. Large up-front grants helped to generate an overall budget surplus of 105 percent of GDP in 1994/95, which became the stock of government assets used to finance deficits in the following years (Table 7). ${ }^{7}$ The deficit in $2000 / 01$ is estimated to bave reached 15 percent of GDP, with an increase in tax revenue and sharp reduction in expenditure being more than offset by a dramatic fall in investment income and much smaller level of grants realized than was expected in the budget. The 2001/02 budget approved by congress would yield an overall deficit of $7 \frac{1}{2}$ percent of GDP, but tax measures are under consideration to bring it to below 5 percent of GDP.

25. Under current practice, the budget presented to congress excludes the majority of grant-financed capital projects, which are included when reporting fiscal operations to the Fund. The authorities' rationale is that these specific projects would not exist unless they secure new capital grants or can utilize unspent balances of capital grants for these capital projects. Thus, the $2001 / 02$ budget, presented to congress targeted a zero balance, whereby expenditures were limited to the total of domestic revenue and Compact grant receipts. The deficit as shown in Table 2 represents staff adjustments to budget assumptions, as well as the excess of capital spending over capital grants, which are to be funanced by new non-Compact capital grants and drawdown of assets (unspent balances of capital grants received in previous years).

\section{Revenue and grants}

26. Tax revenue, mainly from the gross receipts tax (GRT), salaries and wages tax, and the general import tax, ${ }^{8}$ increased significantly in 2000/01, reaching 21 percent of GDP. GRT is paid by businesses at 4 percent on gross revenues (with the exception of financial institutions which pay 4 percent on receipts net of certain deductible expenses). GRT accounts for one-quarter to one-third of total tax revenue, equivalent to 5-6 percent of GDP. Wages and salaries tax is paid by all workers in Palau and accounts for about a quarter of total tax revenue. Revenue from this tax has clearly trended upward: there has been no change in the rate, and the increased yield in recent years reflects improvements in tax

\footnotetext{
${ }^{7}$ A surplus was registered only in $1997 / 98$ due to a one-time revenue gain in the form of a large legal settlement ( $\$ 131 / 4$ million) pertaining to the collapse of a bridge.

${ }^{8}$ Other taxes include hotel occupancy room tax, fish export tax, travelers' head tax (exit tax), vessel cabin and foreign water vessel tax, road-use tax, delinquency tax, tax penalty and interest penalty. Table 15 provides a summary of the various rates.
} 
administration and collection (see below). Revenue from import tax has increased steadily since the mid-1990s as tax rates were raised on cigarettes and alcohol in 1996 and 1998, and a new Customs recording system was introduced in 1999.

27. Nontax revenue has fluctuated, depending on investment income earned on government assets consisting of unspent grant balances (Table 8 ). ${ }^{9}$ The unspent balances of current and capital grants are invested largely in the U.S. and retums constitute investment income. ${ }^{10}$ Investment income peaked in 1999/00 at about

$\$ 14$ million (reflecting the strong U.S. stock market performance). The remaining nontar revenue mainly comprises license and permit fees, interest income on domestically held

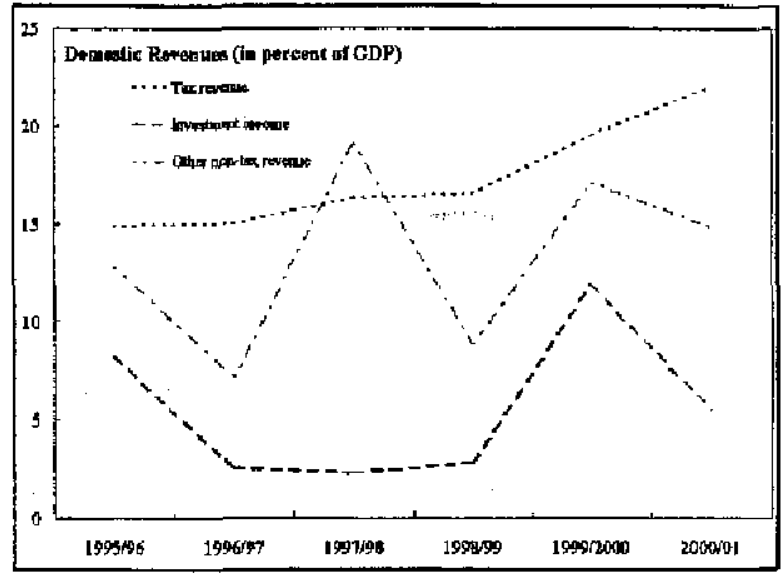
assets, local trust funds, and court fines. These miscellaneous nontax revenues have increased significantly since the mid-nineties. ${ }^{11}$ There has been an upward trend in fees and charges since the mid-1990s - a large part of which is permits for foreign workers-and the peak in $1998 / 99$ reflects the increase in fees for foreign workers' permits.

\section{With the step down in Compact} grants in 1998/99, tax revenue surpassed grant receipts for the first time in 200:/01. As scheduled, Compact grants were steady at over $\$ 20$ million from $1995 / 96-1997 / 98$ and then declined to about $\$ 131 / 2$ million in $1998 / 99$ - the level at which they will remain (with inflation adjustments) through to the end of the Compact period in 2009. Other non-

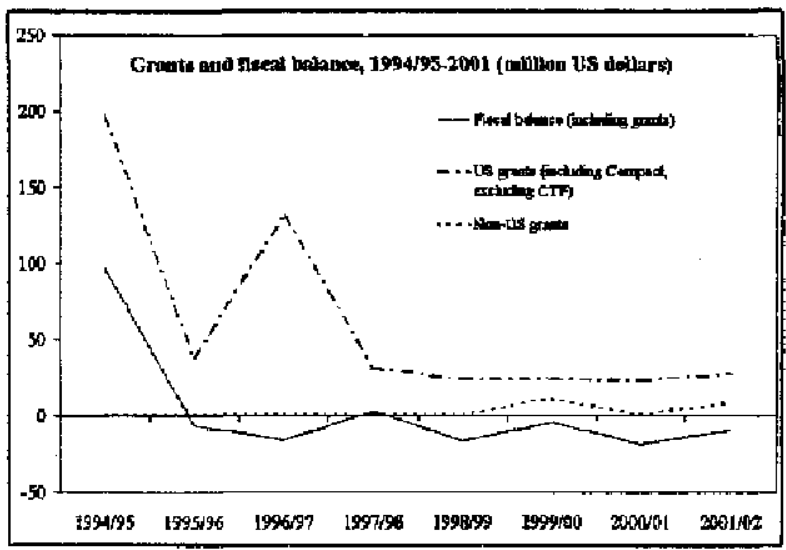

${ }^{9}$ Following staff's advice, unreatized investment gains and losses (amounting to plus or minus 13 percent of GDP) were taken out of nontax revenue and the fiscal balance was revised from 1994/95 onward.

${ }^{10}$ Investment income from the Compact Trust Fund is not included in the budgetary accounts and is treated separately (see below).

11 Local trust funds consist of the K-B Bridge and Operations and Maintenance Trust Fund (from 1997/98), the Hospital Trust Fund, and the Airport Trust Fund. The Palau Visitors" Authority was included as a local trust fund between 1994/95 and 1996/97. 
Compact grants have fluctuated-ranging from $\$ 71 / 2$ million to $\$ 18 / 2$ million, reflecting the lumpy nature of project related grants. The largest single non-U.S. grant has been the $\$ 10$ million grants from Taiwan Province of China in 1999/00. Direct grants for the three large infrastructure projects are not included in budgetary grants because the authorities do not have reliable disbursement information.

\section{Expenditure}

\section{Current expenditure has fluctuated between 47 percent of GDP. and 61 percent} of GDP in recent years. The increase in $1999 / 00$ reflects a tripling of subsidies and transfers over two years to the pension fund in 1999 and 2000 ( $\$ 41 / 4$ million and $\$ 31 / 2$ million, respectively) to cover increased benefits and the earlier mentioned one-off transfer to the NDBP (of $\$ 3$ million) in 2000. Purchases of goods and services also increased sharply in these years, representing supportive expenditure by the government during the economic slowdown in 1998/99 and pre-election spenđing in 1999/00 (Table 9).

30. Fiscal consolidation efforts by the new administrations are geared toward reducing current expenditure relative to GDP. Current expenditures declined to an estimated 52 percent of GDP in $2000 / 01$, and a further reduction to 46 percent of GDP is planned for $2001 / 02$. The decline in $2000 / 01$ is largely explained by cuts in expenditure on goods and services and in subsidies and transfers, particularly to the Civil Service Pension Fund and the Public Utilities Corporation.

\section{Capital expenditure has picked} up to $11 \frac{1}{2}$ percent of GDP in $2000 / 01$ from a low of 7 percent of GDP two years earlier. The increase reflects efforts to secure additional capital grants to supplement the $\$ 2$ million received annually under the Compact, since a large part of the initial $\$ 63$ million Compact capital allocation has been spent. Rehabilitation spending following Storm Utor, financed by Taiwan Province of China and U.S. assistance, also contributed to boosting capital

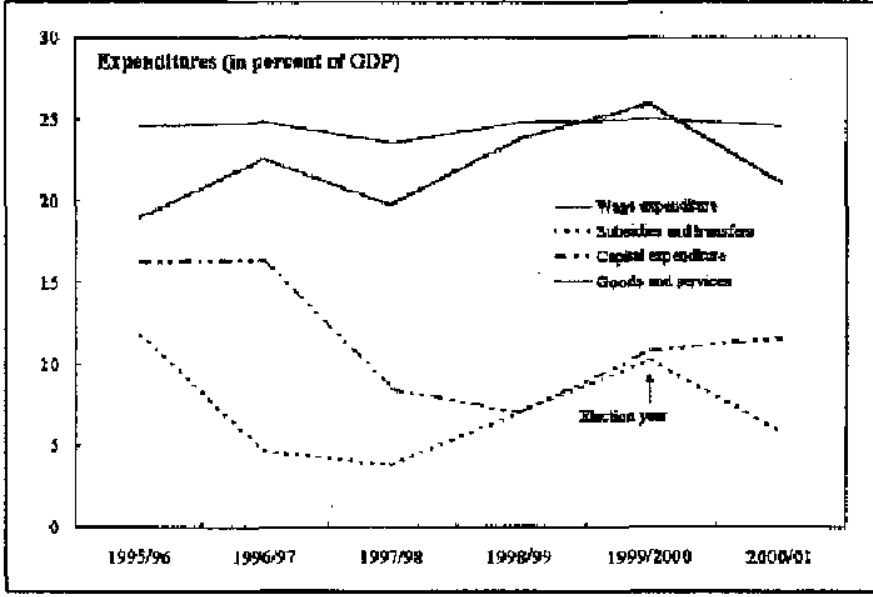
spending. Budget-reported capital expenditure excludes directly financed projects, namely the Compact Road, K-B Bridge, and the new airport terminal building.

\section{B. State Governments}

32. State government accounts are sketchy. Only two state governments have reported their activities to the national authorities since 1998/99 (Table 10). In addition to smal] transfers from the general government, state governments are mainly funded by 85 percent of 
the fishing rights fees, and some local fees and charges (such as motor vehicle registration fees). Expenditures typically cover local wages and salaries, municipal and civic services, and small-scale capital expenditures. The authorities indicated that only two local governments have the authority to borrow, namely Koror (the current capital) and Melekeok (the site of what will be the new capital). Otherwise, states are required to keep spending within available resources, i.e., local revenues plus grants from the national government.

\section{Trust Funds}

33. There are three trust funds administered by the government: the Compact Trust Fund (CTF), the Soclal Security Fund (SSF), and the Civil Service Pension Fund (CSPF). Under the Compact Agreement, the CTF received an initial allocation of \$66 million and an additional \$4 million in 1996/97, and returns were to be largely re-invested until 2009 so as to create a sizable trust fund that would thereafter provide a flow of income to help offset the scheduled loss of Compact grants (Table 8). While there was a provision in the Compact agreement allowing for use of some part of the CTF investment income ( $\$ 5$ million a year from 1998/99 onward, adjusted for inflation at 5 percent), none has so far been used.

34. The CTF grew by an average rate of 13 percent from its inception to June 2001, when its market value was \$147 million. However, its value dropped to \$135 miltion in September 2001, following the substantial correction in the U.S. stock market. The CTF is managed by a number of U.S. fund managers and must be invested only in U.S. equity and fixed income instruments ${ }^{12}$ (Table I1).

35. The SSF, set up under a law enacted in 1991, is self-financing by law and is funded by employee and employer contributions (each of 6 percent on all remuneration paid up to a maximum of $\$ 3,000$ a quarter). ${ }^{13}$ The fund covers employees of public and private employers in Palat, and benefits include old-age insurance benefit (available after the age of 60), disability insurance benefit, and survivor insurance benefit.

36. The SSF grew by an average annual rate of over 20 percent between 1993/941999/00 (Table 12). The funds were invested in U.S. assets, under U.S. fund managers, in the approximate ratio of 35 percent fixed income and 65 percent equity. Annualized returns on

12 The authorities' CTF investment strategy targets investment return of CPI plus 7 percent on equity and CPI plus $31 / 2$ percent on fixed income assets. It also sets forth "desired asset class target allocations," with that for equity 65 percent (with a lower limit of 55 percent and upper limit of 75 percent) and that for fixed income 35 percent (with respective lower and upper limits of 25 percent and 45 percent).

${ }^{13}$ The employee and employer each contributed 4 percent of remuneration under the maximum until September 30, 1996; 5 percent from October 1, 1996 through to September 30, 2001; and 6 percent beginning October 1, 2001. 
equity and fixed income averaged 17 percent and 5 percent, respectively. However, these turned negative in the past year.

37. Although SSF can continue meeting its current obligations from these surpluses, recent changes to benefits have íncreased its unfunded liability from $\$ 15$ million to over $\$ 20$ million. An actuarial study in 2000 (based on 1999 data) indicated that the Social Security System's funding deficiency had decreased from approximately $\$ 19.3$ million as of October 1,1995 , to approximately $\$ 15.3$ million as of October 1,1999 , primarily due to increased contributions. However, based on the changes to benefits in 1999, the unfunded liability is estimated to have increased to $\$ 20.2$ million. These benefit changes include: (i) allowing individuals to receive double benefits (e.g., a retiree could also receive surviving spouse benefits); (ii) removing the incremental reduction in benefits related to income earned; and (iii) tax-exempting the contributions of government to those with titles. There is proposed legislation pending that may successfully reverse parts of the changes, such as the earnings test and the tax-exemption.

38. The Pension Fund has received large government transfers over the past few years (totaling around $\$ 13$ million since 1998) to offset the impact of bigher benefits on the unfunded liabilities. The civil service pension plan, set up in October 1987, provides retirement, death, and disability benefits to civil servants and their families. The CSPF is financed by contributions from government and employees at 6 percent each. The size of the CSPF also grew rapidly over the 1990 s, with revenues much higher than expenditures (Table 13).

39. Investment income on the CSPF has also been high, but unfanded liabilities have increased as the benefits under the plan have been expanded. ${ }^{14}$ Actuarial valuations have been performed periodically, and the latest (seventh) valuation for the fiscal year 2000 indicates that at end-October 1999, the level of under funding was $\$ 24$ million, compared to the previous level of $\$ 14 \% / 4$ million as of end-October 1997 . This increase relates to the government's change in the retirement qualification from the age of 60 to 30 years of service (or which ever came sooner) without reduced benefits before the age of 60 , which became effective on July $1,1999$.

40. The level of under funding is expected to have increased further in 2001, with the rise in benefits as a result of the cost of living adjustment. This is expected to require

\footnotetext{
${ }^{14}$ In 1988 , early retirement was permitted at the age of 55 or 20 years of service (with an associated reduction in benefits for early retirement) and the requirement that retired members contribute 6 percent of benefits was removed; in 1989, various former government workers were brought into the plan; in 1994, the Board of trustees provided for a minimum benefit of $\$ 50$ per month; in 1999, the retirement qualification was changed to either 60 years of age or 30 years of service.
} 
a lump sum transfer of $\$ 71 / 4$ million to the fund to leave the level of under funding unchanged. In 2000/01, a $\$ 1 / 2$ million transfer was made to the fund but there is no allocation in the 2001/02 Budget. The authorities indicated that part of the lease income from the two Intemet gaming concessions (totaling $\$ 2.5$ million annually) would be earmarked for the CSPF. Moreover, the authorities have presented some options to congress for financing the unfunded liabilities.

\section{Performance of Nonfinancial Public Enterprises}

41. The largest nonfinancial public enterprises include the Palau National Communications Corporation (PNCC), Palau International Coral Reef Center, the Public Utility Corporation (PUC), Belau National Museum, the Palau Visitors' Authority, and the Palau Housing Authority (PHA). All but PNCC have received budgetary transfers in recent years. Total transfers to public enterprises amounted to 3 percent of GDP in 2000/01 (Table 14).

42. PNCC recorded a small profit in 2001. This was due to improvements brought about by new management and increased demand for telecommunication and cellular phone services influenced by the recent construction activities in Palau. Higher profits are expected if PNCC becomes a member of National Exchange Carrier Association (NECA) of U.S. ${ }^{15}$

\section{After incurring relatively large losses in the past six years to 1999/00, PUC} expects to have covered their cost of operation for $2000 / 01$. In the past year, wage expenditure declined and tariffs were increased while consumption of electricity rose by 3-4 percent. However, further tariff increases would be needed to avoid a worsening of the financial position in 2002 , as the request for subsidy from the government was declined recently and PUC may be required to expand utility services to more remote parts of the islands.

44. PHA recorded negative operating profit in both 1998/99 and in 1999/00. PHA receives a small subsidy annually to provide low-cost housing for Palauan families, and has registered a small surplus since 1994/95. Recently, U.S. federal contributions, its largest source of revenue, were halted.

\section{E. Public Sector Reforms}

45. A number of public sector reforms have been initlated or are being planned in the near future, as outlined in the government's Management Action Plan (MAP)

\footnotetext{
${ }^{15}$ Formed in 1983 by the Federal Communications Commission (FCC) as a not-for-profit membership corporation, NECA administers the FCC's access charge plan that helps ensure that telephone service remains available and affordable in all parts of the U.S., including remote areas.
} 
doeument issued in March 2001. Legislation was presented to congress in 2001 to introduce tax reforms and to improve its efficiency through performance budgeting and outsourcing functions that can be better performed by the private sector.

46. Proposed new tax legislation Includes administrative provisions for tax and customs and revised import taxes. The tax administration portion of the legislation will formalize improved practices that have already been partly implemented. The legislation also proposes changes to the current tariff structure that would reduce the number of duty bands to a flat rate of 5 percent; rernove certain duty exemptions; switch to valuation imports on a c.i.f. basis from the current use of f.o.b. valuation; and introduces excises on tobacco, alcohol, fuel, boats, and vehicles (Table 15).

47. The passage of the Budget Reform Act, signed into law on July 31, 2001, established performance budgeting and thus provides a system in which government performance can be more readily evaluated. The system is intended to eliminate the duplication of services and ensure the productivity of expenditures. Performance budgeting requires the establishment of program goals and objectives at the agency level, and requires the development of performance indicators as a means of reviewing performance. Such indicators are intended to allow a shift in focus from expenditure on specific line items to the performance of that expenditure and consistency with the overall objectives.

48. As part of the effort to control the public sector wage bill, there has been an Executive Branch wage and hiring freeze since June 2001. The wage and hiring freeze is part of the medium-term objective of "right-sizing" government. Under this decree, positions can only be filled by presidential decree. The hiring freeze is expected to remain in force until a final reorganization structure is in place and a long-term fiscal strategy has been developed. Since June 2001, there is also a moratorium on executive travel, preliminary to the implementation of a comprehensive travel policy. Over the coming year, the right-sizing program will set rules for reorganization by attrition, for retraining and placement programs, and for a severance pay program.

49. Another initiative aiming to right-size government is the planned out-sourcing of services. The Ministry of Administration is currently identifying services that the private sector can provide more efficiently than the public sector. The MAP document refers to the privatization of appropriate government functions, where economically feasible, such as security and janitorial services, maintenance services, and basic infrastructure services to inchude water and sewer services, solid waste disposal, and large government contracts. Other candidates for outsourcing include road repairs, broadcasting, airport operations, and seaports.

50. There are on-going efforts to improve the delivery of health and education services by focusing on cost reduction and increasing the quality of services. Despite declining government transfers in recent years, the hospital has succeeded in increasing medical services by imposing fees equal to about 25 percent of medical costs. Much scope 
remains for improving the quality of education and the cost-effectiveness of government spending. Private as well as public schools currently receive transfers for school lunches. There is a severe shortage of qualified teachers due to recent changes in retirement criteria while student enrollment is increasing.

51. A number of governance reforms are also under way. The Reapportionment Committee reduced the number of Senators from 14 to 9 in January 2001, which is intended to streamline the decision-making process. A constitutional amendment has been proposed to combine the Senate and House of Delegates. Moreover, the National Planning Committee has been reactivated with the objective of providing a more cohesive planning structure within the Executive Branch. This committee has been inactive for several years.

52. The Statistics Act before congress is aimed at strengthening Palau's capacity to collect the necessary data for performance assessment and policy formulation. Notable progress on the compilation and availability of statistics in Palau include: (i) the new GDP data series based on social security data, tax revenue data, and corporate questionnaires; (ii) the compilation of a CPI series since June 2000; and (iii) an on-line processing system for Customs which provides imports data. In addition, the new Financial Institutions Act (FIA) will facilitate regular reporting of banking data, and the new investment regulations will require collection of some basic information on foreign investments.

\section{MONETARY aNd FINANCIAL SECTOR}

53. The banking sector comprises about 12 operating full service commercial banks, 1 development bank, and some 11 other financial institutions, as well as numerous small credit unions. Palau uses the U.S. dollar as its official currency, and has no central bank or monetary survey. Three out of the 12 cperating banks are branches of U.S. banks and subject to U.S. banking regulation. Four other banks are branches of Asian banks, and the remaining five are locally chartered. Of the 11 nombank financial institutions, three are not in operation, and eight provide limited financial services.

\section{A. Commercial Banks}

54. The largest three U.S.-based banks that account for nearly 80 percent of deposits are insured under the FDIC. The Bank of Hawaii alone accounts for more than 60 percent of total deposits. The U.S.-based banks place the majority of their deposits at their headquarters abroad. Most of their local loans are in the form of well-secured consumer loans rather than business loans. Increasing loan activity by these banks would depend on improved financial accounting and disclosure by borrowers and clarification of land ownership and lease rights to facilitate use of land and leases as loan collateral.

55. Banking operations continue to be profitable, based on the large spread between deposit and lending rates. Deposit rates for the period 1997-2000 on 30-day time savings accounts were in the range $2 \frac{1}{4}-5$ percent and on certificates of deposit were in the range of 
4-8 percent (Table 3). This compares with lending rates for the same period of between 10-18 percent for consumer loans and 91/4-13 percent for conmercial loans. ${ }^{16}$ A large share of bank lending is consumer loans; these are thought to be safer, and because they can be typically serviced through direct withdrawals from salary deposits, the level of nonperforming loans is generally low. Available data from corporate reports for nine of the major banks that had submitted their 2000 reports by mid-Septernber $200 \mathrm{I}$ indicated that total deposits were around $\$ 154$ million and total loans were $\$ 56$ million (in 2000) and that in aggregate, profit (the excess of income over expenditures) was positive. The balance of deposits continue to be accumulated and used offshore, suggesting the continued lack of incentives to increase lending in Palau.

\section{B. National Development Bank of Palau}

56. The balance sheet of the National Development Bank of Palau (NDBP) has improved following restructuring by a new management team. A severe deterioration in its balance sheet had sharply curtailed its lending activity in 1999-2000. Af the worst point, around $30-40$ percent of the loan portfolio was in arrears of up to two years. However, with the recent more aggressive approach to collecting, many of these are now serviced and all bad or doubtful loans have been fully provisioned. Its loan guarantees have also been resumed, facilitating lending by foreign banks that cannot accept land as collateral. Proposed legislation in congress aims to help the bank become self-sustaining by allowing it to accept deposits under the same prudential guidelines as other deposit-taking commercial banks, and to issue bonds, which will be guaranteed by the government.

57. The size of NDBP's loan portfolio is currently about $\$ 7$ million, in addition to about $\$ 2$ million of approved undisbursed loans (Tables 16-18). About one-third of the portfolio is in residential housing. In the last year, NDBP has begun to provide the government with quarterly reports of its operations. Loans in arrears for over six months are called judgment loans and these stand at about \$0.7 million. An urgent priority of the bank is to get a systern of credit classification in place. There bas been a recent dialogue with the government about the strategic direction of loans that should be made by NDBP and priority areas under consideration include agriculture, aquaculture, and tourism in addition to housing.

\section{Regulatory and Supervisory Framework}

58. Palau has recently put in place legislation to combat money laundering and increased surveillance practices. The Financial Institutions Act (FIA), approved in 2001, will form the basis for the financial regulation and supervision. Upon reviewing the new

\footnotetext{
${ }^{16}$ There is an interest ceiling of 18 percent on consumer loans and a ceiling of prine plus 4 percent on commercial loans.
} 
legislation in September 2001, the Financial Action Task Force (FATF) decided not to list Palau among the noncooperation countries and territories in the context of money laundering. Palau's review by the FATF had been postponed pending approval and review of the new legislation.

59. The Financial Institutions Commission (FIC) will oversee implementation of the Act. One of its first tasks will be to review the documentation of existing banks against the new guidelines, and to establish banking regulations that will further clarify and strengthen the FIA's provisions. The Act also requires banks to disclose financial statements and to provide regular reports that can form the basis for banking system data to be publicly available in Palau for the furst time.

60. The authorities intend to strengthen the FIA legislation by: (i) removing potential sources of conflict of interest; (ii) clarifying the definition of regulatory capital and raising the capital adequacy requirement to international norms; (iii) requiring adequate recordkeeping, reporting, and external certified auditing of all banks, not only foreign banks; (iv) clarifying the FIC's mandate to request additional reports and conduct on-site inspections, and completing an initial evaluation of all existing banks against the new regulations; and (v) limiting the scope of the banking license granted to banks whose paid-up capital is between the minimum level of $\$ 0.5$ million and $\$ 5$ million. The authorities intend to amend the legislation and/or address these issues through FIC regulations before the end of 2001. Technical assistance from Pacific Financial Technical Assistance Centre (PFTAC) is planned to hejp achieve this objective.

\section{EXTERNAL SECTOR}

61. Palau, like several other small Pacific islands, relies heavily on grant receipts to avoid external imbalances. Palau maintains a large trade deficit. Its export base is narrow, while consumption and investment are highly dependent on imported goods. Tourist receipts, which generate a large share of income in Palau, remain vulnerable to changes in the cxtemal environment. External sector data is extremely weak because of the lack of adequate reporting mechanisms; current and capital private transactions are not fully captured as banks and businesses are not required by law to submit such data.

\section{A. Current Account}

62. The current account deficit (excluding grants) nearly doubled, exceeding 50 percent of GDP in 1999/00 (Table 4). The deficit widened mainly due to a sharp increase in imports associated with construction of infrastucture projects. In 2000/01 the current account deficit is estimated to have retumed to the level of two years earlier as the imports dropped significantly, while service receipts remained relatively flat. Investment income also declined sharply as Palau invests much of its assets in the U.S. stock market. Current grants have remained stable at 15 percent of GDP in the last three years. The current aceount deficit 
including grants was 37 percent of GDP and 13 percent of GDP in for 1999/00 and 2000/01 respectivefy.

\section{Merchandise trade}

63. Palau's exports, accounting for about 10-15 percent of GDP, consist mostly of fish (sashimi-grade tuna beaded for Japan) and garments manufactured by a foreign company. Fish exports had declined in $1997 / 98$ by about 20 percent compared to $1995 / 96$ due to fish migration after El Niño and because Palau began to request all the fishing vessels to install Vessel Monitoring System (VMS) according to international standards.

Subsequently, fish exports rose by 23 percent in $1998 / 99$ as some neighboring countries also began to request fishing vessels to install VMS. In 2000/01, fish exports are estimated to have fallen again by about 33 percent (due to bad weather) to about $\$ 7$ million, compared to a peak of $\$ 13$ million in 1994/95. Gannent exports have become the second largest commodity export in recent years as Chinese investors take advantage of Palau's preferential access to U.S. markets.

64. There was a sharp increase in imports in 1999/00, reaching nearly 110 percent of GDP. After increasing by onethird in 1998/99, imports jumped up by one-half again on account of capital goods needed for major grant-financed infrastructure projects. The largest category of imports is metal products, machinery, and equipment, accounting for 40 percent of total imports. Imports of firel, food, and beverages, which together account for 28 percent of total imports,

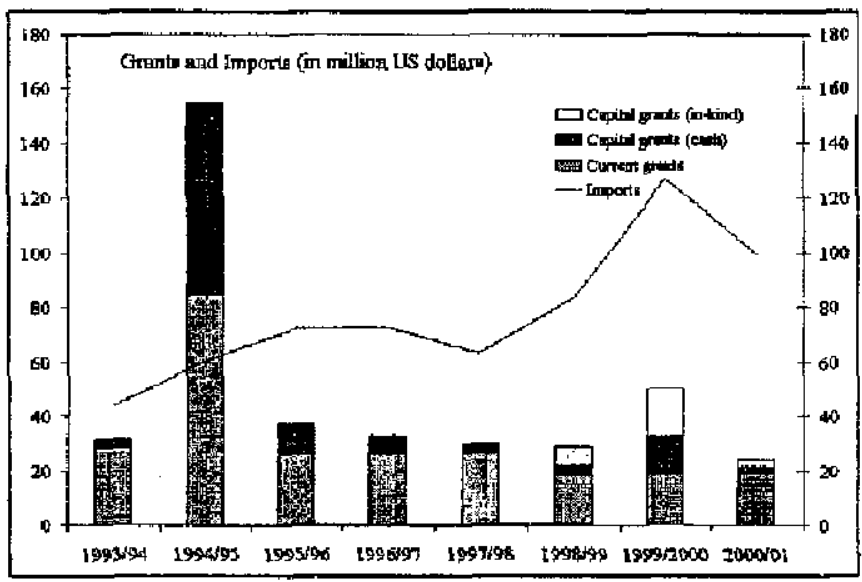
also increased by about 45 percent in 1999/00 (Table 19). The U.S., including Guam account for over 50 percent of total imports (Table 20). Imports are estimated to have declined by 25 percent in 2000/01, as most. construction-related goods required this year had already been imported.

\section{Services, income, and transfers}

65. Service receipts, which amount to 40-55 percent of GDP, consist of tourist receipts, freight and insurance payments, and official travel expenses. Service receipts declined slightly in the previous two years before recovering in 2000/01. Tourists from Japan and Taiwan

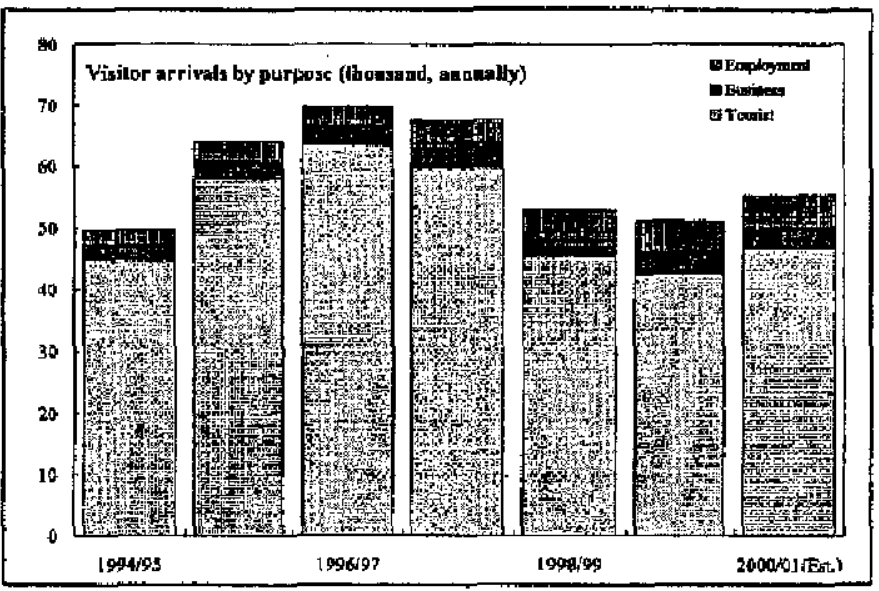


Province of China have declined since the Asian crisis, partly reflecting the relative appreciation of the U.S. dollar compared to Asian currencies. Accordingly, the number of tourist arrivals has not recovered to the level of 1996/97. Service account payments comprise mostly freight and insurance costs, amounting to 17-20 percent of the f.o.b. value of imports.

66. There was a sharp decline in investment income receipts in the year ending September 2001. Investment income consists of jncome from Compact grants (excluding the Trust Fund), the SSF, and CSPF. Investment income from the SSF and CSPF increased substantially by about 120 percent annually in 1998/99 and 1999/00 before falling to 22 percent in 2000/01. Profit rernittances by the foreign fishing and garment companies are estimated at 5-10 percent of GDP annually.

\section{Current transfers have}

fluctuated in recent years, declining by 31 percent in 1998/99 reflecting the reduction in official transfers, mainly grants. Current official transfers include fishing rights fees, FIB permit and employee fees, foreign labor permits, airport uses fees, and port use fees for business licenses and fees. There was an increase in net current transfers by 67 percent in 1999/00 due to a jump in net private inflows, but net transfers declined by 23 percent in 2000/01.

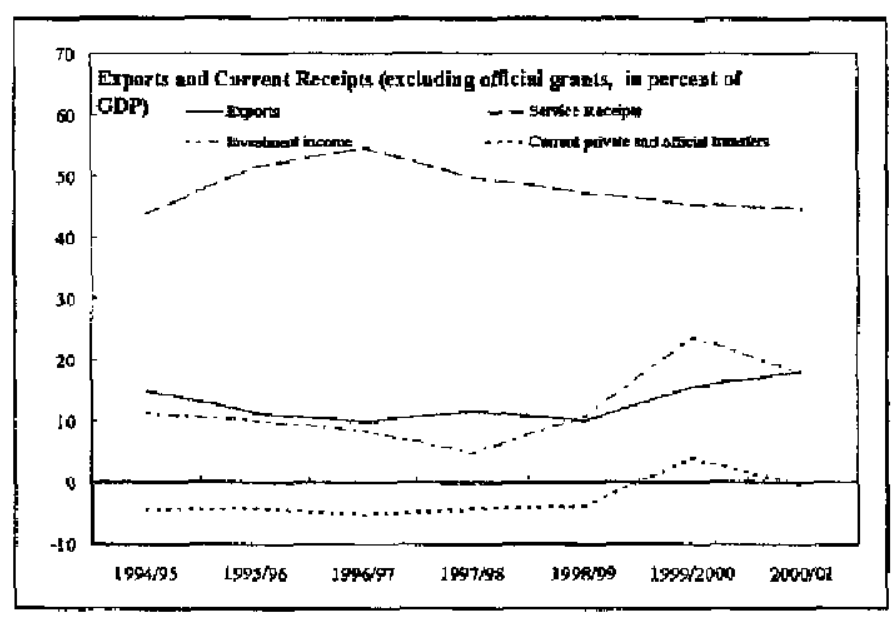

\section{B. Capital Account and Fxterual Debt}

68. Data on capital account transactions continue to be scarce because foreign commercial banks are not required to submit banking statistics to the authorities. The capital and financial account recorded a balance of $\$ 51$ million in 1999/00 from $\$ 7$ million in the previous year due to new borrowing of $\$ 20$ million from Taiwan Province of China for the capital relocation project, an increase in grants received for capital improvements, and directly paid in-kind grants. It declined in $2000 / 01$ to about $\$ 6$ million.

69. In 2000/01, Palau repaid all the debt from financing a power plant. The original debt of $\$ 67$ million was renegotiated in 1993 into an interest-free debt of \$20 million, with a repayment stream of around \$3-4 million for five years starting in 1995 (Table 21). From 2004/05, Palau will begin to make repayments on the loan from Taiwan Province of China.

70. No official data are available for foreign direct investment, and the Foreign Investment Board does not collect information on foreign investments. However, foreign 
investment and other private flows are estimated at 2-12 percent of GDP annually as several tourism-related projects are either wholly or partly financed by foreign private capital.

71. Although Palau has considerable funancial holdings, freely usable government assets are small. There is no definition of official reserves in use. Total financial holdings, excluding the CSPF and SSF assets amount to about $\$ 180$ million (Table 22). However, the largest component of this is the $\$ 135$ million balance of the CTF, of which $\$ 5$ million (inflation adjusted) can be drawn annually. Most of the remaining assets are held abroad, thereby accruing investment income, and are associated with specific capital"projects. Accordingly, freely usable reserves are estimated at about $\$ 8$ million.

\section{Exchange and Trade System}

72. Palau uses the U.S. dollar as national currency. The authorities do not transact in foreign exchange. Most commercial banks handle foreigu exchange transactions and buy and sell foreign currencies based on rates quoted in the international markets. There are no taxes or subsidies imposed on the purchase or sale of foreign exchange. Palau accepted the obligations of Article VIII, Sections 2, 3, and 4 on December 16, 1997.

73. Imports are not subject to any licensing requirements, but importers must obtain a business license to engage in importing activities. Specific and ad valorem taxes are levied under the Customs Rules and Regulations. Most imports are subject to a 3 percent tariff rate. Specific duties are levied on cigarettes, alcoholic products, and other beverages. Proposed legislation, if approved, would convert the specific duties to excise taxes on domestic as well as foreign products.

74. There are no surrender requirements for export proceeds. Exports are not subject to licensing requirements, except with regard to the export of fish. There are no taxes or quantitative restrictions on exports, except that, under the Fish Export Tax Law, a tax is levied on the export of any species of tuna and any species of billfish at the rate of $\$ 0.25$ per kilogram.

\section{There are no restrictions on the payments for or receipts from invisibles.}

76. Foreign investors are required to submit applications to the Foreign Investment Board and obtain an approval certlficate to engage in business or to acquire an ownership interest in a business in Palau. As noted earlier, some business activities are reserved exclusively for Palauan citizens or business enterprises wholly owned by Palauan citizens. There are no special financial incentives offered to foreign investors, except those available under certain provisions of the Compact (for example, duty-free access to the U.S. markets for some products). As noted earlier, foreign ownership of real estate is prohibited, but foreigners can obtain long-term leases extending up to 50 years. There are no restrictions on the repatriation of profit or capital. Recently proposed legislation may relax some of the restrictions on foreign investment. 
Table 1. Republic of Palau: Selected Economic and Financial Indicators, 1993/94-2000/01 1/

Nominat GDP (2000): US\$118.2 mitlion

Population (2000): $\quad 19,129$

GDP per capita (1999): USS6,179

\begin{tabular}{|c|c|c|c|c|c|c|c|c|}
\hline & $1993 / 94$ & $1994 / 95$ & $1995 / 96$ & $1996 / 97$ & $1997 / 98$ & $1998 / 99$ & $1999 / 00^{\circ}$ & $\begin{array}{c}\text { Est. } \\
2000 / 01\end{array}$ \\
\hline & \multicolumn{8}{|c|}{ (In millions of U.S, dollars, unless otherwise specified) } \\
\hline \multicolumn{9}{|l|}{ Real sector } \\
\hline Nominal GDP $2 t$ & 83.5 & 95.2 & 108.2 & 113.2 & 117.3 & 113.5 & 118.2 & 122.5 \\
\hline (Percent ehange) & 10.1 & 14.0 & 13.6 & 4.6 & 3.6 & -3.3 & 4.2 & 3.6 \\
\hline GDP deflator $3 i$ & 2.6 & 2.8 & 2.9 & 2.3 & 1.6 & 2.2 & 3.0 & 2.6 \\
\hline Real GDP (percent change) & 7.3 & $\$ 0.9$ & 10.4 & 2.3 & 2.0 & -5.4 & 0.1 & 1.0 \\
\hline Nominal GDP (FY) & 81.6 & 92.3 & 105.0 & 112.0 & 116.3 & 114.4 & 117.0 & 121.4 \\
\hline Business and tourist arnivals & 37,578 & 47,023 & 60,719 & 66,441 & $63,6.56$ & 49,170 & 45,932 & 49,731 \\
\hline Tourist spending & 29.4 & 40.6 & 54.2 & 61.2 & 58.0 & 54.1 & 53.2 & 54.3 \\
\hline \multicolumn{9}{|l|}{ Pnbtic finance } \\
\hline \multicolumn{9}{|l|}{ Central goversmenr. } \\
\hline Reyenuas & 49.6 & 165.1 & 66,5 & 58.0 & 71.3 & 51.0 & 75.0 & 61.6 \\
\hline Domestic & 18,8 & 22.1 & 29.1 & 24.9 & $4: .3$ & 29.0 & 42.9 & 40.2 \\
\hline Grants & 30.9 & 143.0 & 37.5 & 33.2 & 30.0 & 22.0 & 32,1 & 21.4 \\
\hline Expenditures & 50.4 & 65.3 & 75.1 & 76.5 & 54,6 & 71.7 & 84.5 & 77.2 \\
\hline Current: & 47.4 & 56.7 & 58.1 & 58.3 & 54.8 & 63.7 & 71.8 & 63.1 \\
\hline Capital & 3.0 & 8.5 & 17,0 & 18.3 & 9.9 & 8.0 & 12.7 & 14.1 \\
\hline Overall fiscal balance (including granis) & -0.4 & 97.3 & -6.6 & -16.3 & 2.4 & -16.8 & -4.7 & -18.5 \\
\hline (In perecatage of GDP) & -0.5 & 105.4 & -6.3 & .14 .5 & 2.1 & -14.7 & -4.0 & -15.2 \\
\hline Overall fiscal balance (excluding grants) & -31.2 & -45.7 & -44.1 & -49.5 & -27.5 & 48.8 & $-36 . ?$ & -39.9 \\
\hline (In percentage of GDP) & -38.3 & -49.6 & -42.0 & 44.2 & -23.7 & -33.9 & -31.4 & -32.9 \\
\hline Compact Trust Fund (CTH) balance $4 /$ & 0.0 & 70.8 & 77.2 & 105.5 & 122.4 & \$41.] & 169.8 & 135.0 \\
\hline Revenues & $\ldots$ & 71.0 & 7.0 & 28.9 & 17.6 & 19.6 & 21.5 & .25 .8 \\
\hline Expendinures & $\ldots$ & 0.3 & 0.6 & 0.5 & 0.8 & 0.8 & 0.8 & 10 \\
\hline Govemment assets (non-Trast Fund assets) & 0.5 & 97.5 & 84.1 & 81.0 & 85.1 & 67.0 & $7 \%, 7$ & 44.0 \\
\hline Balance of capital grants $5 /$ & $\ldots$ & 61.6 & 55.9 & 44.7 & 38,4 & 33.8 & 53.8 & 41.9 \\
\hline Ealance of current grants $5 /$ & ... & 38.2 & 35.3 & $31 . \mathrm{t}$ & 44.1 & 28.0 & 18.5 & 14.7 \\
\hline Balance of usable reserves (exciuding CTF) 6 & $\ldots$ & 35.1 & 30.3 & 36.1 & 43.4 & 38.9 & 29.4 & 7.6 \\
\hline \multicolumn{9}{|l|}{ Balance of payments } \\
\hline Trade balance & -31.7 & -46.6 & .58 .5 & -61.5 & -52.1 & -70.3 & -115.6 & -80.8 \\
\hline Exports (f.o.b.) & 12.6 & 13.9 & 13.9 & 11.8 & $1[.1$ & 13.6 & 11.5 & 18.3 \\
\hline Imports (f.o.b. & -44.2 & -60.4 & -72.4 & -72.9 & -63.2 & -83.9 & -127.1 & -99.1 \\
\hline Current account belarxe (inchuding grants) & $2 . B$ & 60.7 & 1.4 & 4.2 & 9.7 & -14.3 & -42.7 & 15.7 \\
\hline (In percentage of GDP) & 3.4 & 65.8 & 1.3 & 3.7 & 8.4 & -12.5 & -36.5 & -12.9 \\
\hline Current accounst balance (excluding granis) & -25.6 & -23.9 & -24.8 & -21.9 & -16.7 & -33.0 & -62.0 & -34.8 \\
\hline (In percentage of GDP) & -31.3 & -25.9 & -23.6 & -19.6 & $-14,4$ & -28.8 & -52.9 & -28.7 \\
\hline Overall balance & -0.8 & 92.8 & -9.6 & -16.6 & -1.2 & -20.9 & 13.9 & -18.5 \\
\hline External debt & 20.0 & 15.5 & 12.5 & 9.1 & 5.5 & 1.4 & 20.0 & 20.0 \\
\hline External debt service & $\ldots$ & 4.5 & 3.0 & 3.4 & 3.6 & 4.1 & 1.4 & 0.7 \\
\hline
\end{tabular}

Souces: Data provided by the Patauan aufhorities; and Fund staff estimates.

V Fiscal year beginning October 1.

2/ On a calendar year basis. The column $1995 / 96$ refers to $[996$, and 50 forth.

3/U.S. CPI is used as GDP deflawor for 1995 to 1999 . Palau began compiling CPI fom June 2000, therefore, GDP dellator for year 2000

is the average of U.S. defator and Palau CPL. For 2001, Falau CPI is used as deflator.

4/ Covers operations of the Tnist Fund from 1994/95.

5/ Staff estimate of the umused balance of grant receipts. Capital and current balance do not add to total because of valuation losses in $200 \mathrm{~s}$. 6/ Usabie reserves estinated as the government financial butance plus annual drawable amount from CTF less the balance of eapital giants. 
Table 2. Republic of Palau: Balance of Payments, 1994/95-2000/01 (In thousands of U.S. doilars)

\begin{tabular}{|c|c|c|c|c|c|c|c|}
\hline & $1994 / 55$ & $1995 / 96$ & $1996 / 97$ & $1997 / 98$ & $1998 / 99$ & $1999 / 2000$ & $\begin{array}{r}\text { Est } \\
2000 / 01\end{array}$ \\
\hline Trade balance & $-46,569$ & $-58,517$ & $-61,082$ & $+52,127$ & $-70,278$ & $-115,619$ & $.80,837$ \\
\hline Expors, fo.b. & 13,868 & 13,907 & 11,812 & 11,094 & 13,574 & 11,509 & 18,267 \\
\hline Impors, fo.b. L/ & $-60,438$ & $-72,424$ & $-72,894$ & $-63,22$ & $-83,852$ & $-127,127$ & $-99,104$ \\
\hline Services atceourt & 23,958 & 34,447 & 41,203 & 40,292 & 35,443 & 25,794 & 32,756 \\
\hline Receipts & 40,554 & 54,213 & 61,220 & 58,003 & 54,144 & 53,240 & 54,307 \\
\hline Travel & 40,554 & 54,213 & 61,220 & 58,003 & 54,144 & $\$ 3,240$ & 54,307 \\
\hline Payments & $-16,596$ & $-19,766$ & $-20,016$ & $-17,711$ & $-18,701$ & $-27,445$ & $-21,551$ \\
\hline Freight and insuruace & $-15,109$ & $-18,106$ & $-18,223$ & $-15,805$ & $-16,770$ & $-25,425$ & $+19,821$ \\
\hline Travel & $-1,487$ & $-1,660$ & $-1,793$ & $-1,906$ & $-1,931$ & $\begin{array}{l}-2,020 \\
\therefore\end{array}$ & $-1,730$ \\
\hline Insome & 2,832 & 3,788 & 3,872 & $27 !$ & 6.215 & 23,236 & 14,028 \\
\hline Investonent incons 2 & 10,458 & 10,522 & $9, \$ 10$ & 5,608 & 12,204 & 27,782 & 21,575 \\
\hline Heome and interest payment i/ & $-7,025$ & $-6,734$ & $-5,538$ & $-5,337$ & $-5,989$ & $-4,546$ & $-7,547$ \\
\hline Cumrent transers & 80,499 & 21,659 & 20,180 & 21,306 & 14,288 & 23,926 & 18,368 \\
\hline Private & $-4,818$ & $-5,408$ & $-6,404$ & $-6,062$ & $-3,680$ & 3,272 & $-1,899$ \\
\hline Inflaws & 880 & 983 & 1,062 & $\downarrow, 129$ & 1,500 & 11,135 & 5,686 \\
\hline Ontflows & $-5,698$ & $-6,391$ & $-7,466$ & $\cdot 7,190$ & $-7,180$ & $-7,862$ & $-7,585$ \\
\hline Official & 85,317 & 27,067 & 26,584 & 27,368 & 19,968 & 20,654 & 20,267 \\
\hline Business licenses and few & 1,001 & 1,000 & 867 & 1,724 & 1,915 & 1,933 & 1,728 \\
\hline Grants & 84,643 & 26,161 & 26,098 & 26,435 & 18,624 & 19,298 & 19,128 \\
\hline Other $4 /$ & .327 & -95 & -381 & .791 & -571 & -577 & $-\$ 89$ \\
\hline $\begin{array}{l}\text { Curent account } \\
\text { (includes official grathes) }\end{array}$ & 60,720 & 1,377 & 4,173 & 9,742 & $-14,332$ & $-42,663.3$ & $-15,685$ \\
\hline $\begin{array}{l}\text { Current account } \\
\text { (excludes official grants) }\end{array}$ & $.23,923$ & $-24,784$ & $-21,975$ & $-16,693$ & $-32,956$ & $.61,961$ & $-34,813$ \\
\hline Capital and financial account & 65,674 & 10,291 & 5,674 & 14,146 & $7,0,03$ & $51,4 B A$ & 6,144 \\
\hline Pvblix sector & 65,674 & 8,291 & 3,674 & -54 & 6,003 & 49,484 & 5,144 \\
\hline Coupical pranis $5 I$ & 70,174 & 11,291 & 7,074 & 3,546 & 3,369 & 12,764 & 2,179 \\
\hline In-lind capital grants & $\cdots$ & $\cdots$ & $\ldots$ & $\cdots$ & 6,701 & 18,154 & 2,965 \\
\hline Gross borrowing & $\cdots$ & $\cdots$ & $\cdots$ & $\cdots$ & $\cdots$ & 20,000 & $m$ \\
\hline Lasn repaytrents & $-4,500$ & $-3,000$ & $-3,400$ & $-3,600$ & $-4,067$ & $-1,434$ & 0 \\
\hline Private Sector & $\cdots$ & 2,000 & 2,000 & 14,200 & $\$, 100$ & 2,000 & 1,000 \\
\hline Foreign direct investrent 6 & $\cdots$ & 2,000 & $2,0,00$ & 1,000 & $1,0,00$ & 2,000 & 1,000 \\
\hline Other private inflows & $\cdots$ & $\because$ & $\ldots$ & 13,200 & $\cdots$ & $\cdots$ & $\cdots$ \\
\hline Cumest phes capisal account & 126,394 & $1 !, 66\}$ & 9,847 & 23,888 & $-7,329$ & 8,821 & $-9,541$ \\
\hline Error and ornissions $7 /$ & $-33,618$ & $-21,284$ & $-26,481$ & $\cdot 25,051$ & $-13,524$ & 5,078 & $\$, 938$ \\
\hline Gverall balaree 8 f & $92,7,6$ & $-9,616$ & $-16,633$ & $-1,163$ & $-20,853$ & 13,899 & $-18,479$ \\
\hline \multicolumn{8}{|l|}{ Memorandwn ireens: } \\
\hline Impocts/GDP (m perecmi) & -65.5 & -69.0 & -65.1 & -54.4 & -73.3 & -108.6 & -81.6 \\
\hline Import duries/GDP & 3.4 & 3.1 & 3.4 & 3.8 & 4.3 & 5.5 & 5.3 \\
\hline \multicolumn{8}{|l|}{ Current accoumb/GDP (in percent) } \\
\hline Inchiding afficial grints & 65.8 & E.3 & 3.7 & 8.4 & -12.5 & -36.5 & -12.9 \\
\hline Excluding official grants & -25.9 & -23.6 & -19.6 & -14.4 & -38.8 & -52.9 & -28.7 \\
\hline Service receipts/GDP (ìn percenl) & 43.9 & 51.7 & 54.7 & 49.9 & 47.3 & 45.5 & 44.7 \\
\hline REER appreciation (12 month basis) & I.1 & 3.1 & 5.4 & $|1|$. & -6.5 & 2.8 & 8.0 \\
\hline Reserves in montas of inports & 19.2 & 14.3 & 13.3 & 15.5 & 9.7 & 7.4 & 5.3 \\
\hline Exterial debtreserve ratio & 0.2 & 0.1 & 0.1 & 0.1 & 0.3 & 0.3 & 0.5 \\
\hline
\end{tabular}

Sonnes: Data provided by the Palau authortities; and Fund staff estimates.

W/ Includes direct financed axd project inpors and orher tax-exempt imports.

2 lncludes restized imvestrent gring and losses.

$3 /$ [ncludes estimates of profit repatrizion by foraign fiah and garment expon cortupaties.

4/ Contribution to intemational and regional organizations.

5i Lreludes $\$ 13$ mullion in $1997 / 98$ for K-B bridge setrlement and excludes grents-in-jcind.

6/ Staff estimates on investrnents in thew hotelsiresors tor $1999 / 00$ and $2000 / 01$,

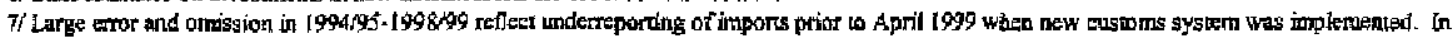
addition, net private current inflows are underestimated as inflows ate only reported by one bant in Palau.

$8 /$ Reflects the changes in the fmamcial holdimgs of the government exchuding Compact Trust Fund's non-Trust Fund Asset (NTFA). 
Table 3. Republic of Palau: Structure of Interest Rates, 1997-2000

(in percent)

\begin{tabular}{|c|c|c|c|c|}
\hline & 1997 & 1998 & 1999 & 2000 \\
\hline \multicolumn{5}{|l|}{ National Development Bank of Palau } \\
\hline \multicolumn{5}{|l|}{ Lending rates } \\
\hline Commencial loans (one year) & $\ldots$ & 0.0 & 0.0 & $10.0-12.0$ \\
\hline \multicolumn{5}{|l|}{ Residential housing loans } \\
\hline 30-year, fixed (maximpun 20 year) & $\ldots$ & 0.0 & 0.0 & $8.0-12.0$ \\
\hline 15-year, fixed & $\cdots$ & 120 & 12.0 & 12.0 \\
\hline Govemnent-dirached scheme $1 /$ & 0.0 & 0.0 & 0.0 & 8.0 \\
\hline Nonmal loan schame & $\cdots$ & 12.0 & 12.0 & 12.0 \\
\hline \multicolumn{5}{|l|}{ Summary of Commercial Banks } \\
\hline \multicolumn{5}{|l|}{ Deposit rates } \\
\hline Checking account (with minimum balance) & $0.00-4.50$ & $0.00-5.00$ & $0.00-5.00$ & $0.00-5.00$ \\
\hline Savings account & $2.25-5.00$ & $225-4.75$ & $2.25-4.75$ & $2.25-4.75$ \\
\hline \multicolumn{5}{|l|}{ Time savings account } \\
\hline 30 days & $2.25-5.00$ & $2.25-4.75$ & $2.25-4.75$ & $2.32-4.75$ \\
\hline One year & $4.50-6.00$ & 4.65 & 3.65 & 5.35 \\
\hline \multicolumn{5}{|l|}{ Centifiates of deposit } \\
\hline Six months & $4.12-5.00$ & $3.75 \cdot 5.00$ & $3.02-5.00$ & $3.65 \cdot 5.00$ \\
\hline One year & $2.25-6.00$ & $2.25-6.00$ & $2.25-6.00$ & $3.75-6.00$ \\
\hline Two years & $4.25-7.00$ & $4.36-7.50$ & $3.35-7.50$ & $3.95-7.50$ \\
\hline Three years & $4.31-8.00$ & $4.36-8.00$ & $3.75-8.00$ & $4.00-8.00$ \\
\hline \multicolumn{5}{|l|}{ Lending rates } \\
\hline Consumer loars & $15.00-18.00$ & $15.00-18.00$ & $11.00-18.00$ & $9.90-18.00$ \\
\hline Comnercial loans (one year) $2 /$ & $9.50-12.75$ & $9.50-12.75$ & $9.25-12.50$ & $9.75-13.00$ \\
\hline \multicolumn{5}{|l|}{ Residential bousing loans } \\
\hline 30-year, fixed $3 /$ & 1200 & 12.00 & 9.00 & 9.00 \\
\hline 15-year, fixed 3/ & 12.00 & 10.00 & 8,00 & 8.00 \\
\hline
\end{tabular}

Sources: Data provided by the Palau National Development Bank (PNDB) and individusl commercial banks.

1/ Under gowemment-directed lcan scherne, loan is provided to Palauans who have never owned a house.

2/ Bank of Hawaii commercial loan rates follow the highest New York Prime phus 4 percent; between 1998 and 2001.

3/ Rates between 1998-2000 are those for Bank Pacifie Ltd, (Guarn Savings Bank). 
Table 4. Republic of Palau: Gross Domestic Product, 1995-2001

\begin{tabular}{|c|c|c|c|c|c|c|c|}
\hline & $\begin{array}{r}1995 \\
1 /\end{array}$ & $\begin{array}{r}1996 \\
2 J\end{array}$ & 1997 & 1998 & - 1999 & 2000 & $\begin{array}{r}2001 \\
\text { Est. }\end{array}$ \\
\hline & \multicolumn{7}{|c|}{ (In thousands of U.S. dollars) } \\
\hline Agriculture & 1,579 & 1,231 & 1,312 & 1,398 & 1,358 & 1,372 & 1,399 \\
\hline Fisheries & 3,918 & 2,973 & 2,057 & 2,038 & 3,148 & 3,290 & 3,388 \\
\hline Mining and quarrying & 301 & 158 & 138 & 176 & 218 & 229 & 245 \\
\hline Mamufacturing & 851 & 997 & 1,403 & 1,702 & 1,609 & 1,706 & 1,808 \\
\hline Electricity, gas, and water & 303 & -8 & -3.88 & 2,360 & 3,393 & 3,610 & 3,863 \\
\hline Construction & 7,395 & 3,545 & 8,834 & 10,389 & 8,249 & 8,909 & 9,621 \\
\hline Trade & 18,238 & 20,995 & 23,913 & 24,837 & 23,165 & 24,091 & 25,175 \\
\hline Hoteds and restaurants & 12,794 & 15,360 & $13,9: 86$ & $\mathbf{I 2 , 3 7 0}$ & 11,938 & 11,998 & 12,082 \\
\hline Transport and communication & 8,345 & 7,270 & 8.734 & 9,191 & 9,846 & 10,535 & 11,272 \\
\hline Finance and insurance & 4,210 & 5,294 & 6,573 & 5,706 & 4,297 & 4,554 & 4,828 \\
\hline Real estate and business scrvices & 6,262 & 7,570 & 6,298 & 6,555 & 4,611 & 4,888 & 5,108 \\
\hline Public administration & 23,203 & 26,813 & 29,401 & 28,462 & 29,374 & 30,373 & 30,816 \\
\hline Other services & 6,480 & 9,807 & 9,211 & 9,907 & 9,691 & 10,059 & 10,260 \\
\hline Subtotal & 93,879 & 107,006 & 111,471 & 115,091 & 110,897 & 115,614 & 119,867 \\
\hline Less: Imputed bank service charge & 1,743 & 2,100 & 2,101 & 2,640 & 2,384 & 1,250 & 1,250 \\
\hline Plus: Import duties & 3,101 & 3,298 & 3,842 & 4,869 & 4,972 & 3,842 & 3,842 \\
\hline Gross domestic product & 95,237 & 108,204 & 113,212 & 117,320 & 113.485 & 118,206 & 122,459 \\
\hline Nominal GDP (fiscal ytar) & 92,309 & 104,962 & 111,960 & 116,293 & 114,444 & 117,026 & 121,396 \\
\hline \multicolumn{8}{|l|}{ Memoranduro iterns: } \\
\hline Nominal GDP growth & 0 & 14 & 5 & 4 & -3 & 4 & 4 \\
\hline Real GDP growth $3{ }^{\prime}$ & -8 & 10 & 2 & 2 & -5 & 1 & 1 \\
\hline GDP deflator & 3 & 3 & 2 & 2 & 2 & 3 & 3 \\
\hline$\cdot$ & \multicolumn{7}{|c|}{ (Percentage change) } \\
\hline Agiculture & -18.0 & -22.0 & 6.6 & 6.5 & -2.8 & 1.0 & 2.0 \\
\hline Fishteries & -19.4 & -24.1 & -30.8 & -0.9 & 54.5 & 4.5 & 3.0 \\
\hline Mining and quarrying & -32.2 & -47.6 & $-12,4$ & 27.7 & 23.6 & 5.0 & 7.0 \\
\hline Manufacturing & 20.7 & 17.1 & 40.7 & 21.3 & -5.5 & 6.0 & 6.0 \\
\hline Electricity, gas, and water & -50.6 & -102.5 & $5,002.0$ & -707.6 & 43.8 & 6.4 & 7.0 \\
\hline Construction & 53.5 & 15.6 & 3.4 & 17.6 & -20.6 & 8.0 & 8.0 \\
\hline Finance and insurance & 34.6 & 25.7 & 24.2 & -13.2 & -24.7 & 6.0 & 6.0 \\
\hline Real stale and business services & 26.4 & 20.9 & -16.8 & 4.1 & -29.7 & 6.0 & 4.5 \\
\hline Public administration & 0.9 & 15.6 & 9.6 & -3.2 & 3.2 & 3.4 & 1.5 \\
\hline Other services & 4.4 & 51.3 & -6.1 & 7.6 & -2.2 & 3.8 & 2.0 \\
\hline \multicolumn{8}{|l|}{ Subtotal } \\
\hline Less: Imputed bank service charge & 25.7 & 20.5 & 0.0 & 25.6 & -9.7 & -47.6 & $\ldots$ \\
\hline Plus: Irport duties & 6.8 & 6.4 & 16.5 & 26.7 & 2.1 & -22.7 & ... \\
\hline Nominal GDP (fiscal year) & 13.1 & 13.7 & 6.7 & 3.9 & -1.6 & 2.3 & 3.7 \\
\hline ROP deflalor & 28 & 2.9 & 2.3 & 1.6 & 2.2 & 3.0 & 2.6 \\
\hline
\end{tabular}

Sources: Data provided by Corporate Registrar, Sacial Security, and Government Audit Reports.

1/ Data for 1995 have bect estimated using indicators for tourism, trade, and public administration between 1993 and 1996 benchuarks.

$2 /$ Dats for 1996 to 2001 have been estimated by a UNDP statistics specialist.

3/ U.S. CPI is used as GDP deflator for 1995 to 1999 . Palau began compiling CPI from Jume 2000, therefore, GDP deflator for year 2000 is the average of the U.S. and Palau CPJ. For 200L, Polau CPI is used as deflator. 
Table 5. Republic of Palau: Visitor Arrivals by Purpose and by Country of Residency, 1996-2001

\begin{tabular}{|c|c|c|c|c|c|c|}
\hline & 1996 & 1997 & FY 1998 & FY 1999 & FY 2000 & FY 2001 \\
\hline \multicolumn{7}{|l|}{ Tonrism 1} \\
\hline \multicolumn{7}{|l|}{ Visitor arrivals by purpose } \\
\hline Tourist & 58,022 & 63,601 & 59,780 & 45,462 & 42,470 & 46,684 \\
\hline Business & 2,697 & 2,840 & 3,876 & 3,708 & 3,462 & 3,047 \\
\hline Employment & 3,347 & 3,425 & 3,926 & 3,746 & 5,064 & 5,590 \\
\hline Other 2 & 5,264 & 3,853 & 1,346 & 3,944 & 5,506 & 274 \\
\hline \multicolumn{7}{|c|}{ Total arrivals by country of residency } \\
\hline Taiwan Province of Ching & 22,523 & 30,497 & 24,173 & 12,754 & 14,390 & 14,077 \\
\hline Japan & 21,410 & 19,519 & 21,567 & 22,651 & 21,140 & 23,303 \\
\hline Unitef States & 8,878 & 9,400 & 12,255 & 11,807 & 8,072 & 8,456 \\
\hline Korez & 1,907 & 1,640 & 697 & 610 & $\$ 92$ & 451 \\
\hline Australia and New Zealand & 1,212 & 500 & 602 & 550 & 402 & 390 \\
\hline Philippines & 854 & 879 & 3,130 & 2,863 & 3,819 & 4,164 \\
\hline Other & 12,546 & 11,284 & 6,554 & 5,231 & 8,087 & 4,754 \\
\hline Total arrivals & 69,330 & 73,719 & 68,928 & 56,466 & 56,502 & 55,595 \\
\hline
\end{tabular}

Source: Data provided by the Palan Visitors Authority.

$1 /$ On a calendar year basis up to 1997.

2/ Other includes retuming residents, fishennen, crews, studects, transits, and dependents. 
Table 6. Republic of Palau: Employed Persons by Industry, 1990, 1995, 1999, and 2000

\begin{tabular}{|c|c|c|c|c|}
\hline & $\begin{array}{r}1990 \\
\text { Census }\end{array}$ & $\begin{array}{r}1995 \\
\text { Census }\end{array}$ & $\begin{array}{l}1999 \\
\text { sso }\end{array}$ & $\begin{array}{r}2000 \\
\text { Census }\end{array}$ \\
\hline Agriculture, fisheries, and mining & 446 & 724 & 287 & 215 \\
\hline Construction & 861 & 1,087 & 946 & 1,112 \\
\hline Manufacturing & 93 & 78 & 26 & 345 \\
\hline $\begin{array}{l}\text { Transport, storage, communication, and } \\
\text { other public utilities }\end{array}$ & 477 & 435 & 766 & 765 \\
\hline Wholesale, retail, restaurants, and hotels & 800 & 1,448 & 2,495 & 2,619 \\
\hline Finance, insurance, and real estate & 119 & 122 & 119 & 116 \\
\hline Services $1 t$ & 687 & 1,573 & 1,147 & 1,246 \\
\hline Public administration & 2,116 & 2,292 & 3,048 & 3,203 \\
\hline Total employed population & 5,599 & 7,759 & 8,834 & 9,621 \\
\hline
\end{tabular}

Sources: Office of Planning and Statjstics, 1994 and 1999 Statistica! Yearbook; 1995 and 2000 Census of Population and Housing, and Social Security Office (SSO) for 1999.

1/ Includes business, repair, personal, community, entertainment, recreation, health, education, and other social services. 
Table 7. Republic of Palau: National Government Budgetary Operations, 1994/95-2001/02

\begin{tabular}{|c|c|c|c|c|c|c|c|c|c|}
\hline & $1994 / 95$ & $1999 / 96$ & $1996 / 97$ & $1997 / 98$ & $1998 / 99$ & $1999 / 2000$ & $\begin{array}{c}200001 \\
\text { Estimated }\end{array}$ & $\begin{array}{c}\text { 2001/az } \\
\text { Budpel } \\
\text { Aspassod } \mathrm{V} \\
\end{array}$ & $\begin{array}{c}2001 / 02 \\
\text { Butigen } \\
\text { Proposed 2/ } \\
\end{array}$ \\
\hline & \multicolumn{9}{|c|}{ (It thousands of U.S. dollats) } \\
\hline Total neverune and grants & 165,086 & 66,538 & 58,036 & 71,306 & $51, B 17$ & 74,984 & 61,493 & 70,058 & 75,233 \\
\hline Domestic tevetme & 22,069 & 29,087 & 24,864 & 41,325 & $29,02 \mathrm{~A}$ & 42,922 & 40,186 & 35,422 & 40,597 \\
\hline Tax reranue & 13,351 & 15,637 & 16,829 & 19,037 & 18,925 & 22,879 & 25,762 & 25,195 & 30370 \\
\hline Salarim and wiges & 3,827 & 4,096 & 4,620 & 4,720 & 5,152 & 5,480 & 6,315 & 5,827 & 6,527 \\
\hline Inpout tex & 3,136 & 3,298 & 3,950 & 4,410 & 4,973 & 6,433 & 6,473 & 6,138 & 30,338 \\
\hline Gross revelibe tax & 4,774 & 6,058 & 6,260 & 6,260 & 5,615 & 6,184 & 7,145 & 5,617 & 6,617 \\
\hline Other & 1,619 & 2,175 & 2,099 & 3,647 & 3,185 & 4,782 & $5,1,829$ & 5,613 & 6,588 \\
\hline Nontax revenue & 8,719 & 13,450 & 8,036 & 22,288 & 10,099 & 20,042 & 14,424 & 10,227 & 10,227 \\
\hline Fistining rights incallic & 230 & 210 & 130 & 120 & 137 & 39 & 76 & 134 & 134 \\
\hline Intextest income & 56 & 79 & 68 & 81 & 69 & 253 & 1,875 & 879 & 879 \\
\hline Fees ind charges & 1,247 & 1,195 & 1,158 & 1,440 & 2,950 & 2,113 & 2,573 & $2,9 \mathrm{~B} 4$ & 2,984 \\
\hline Other & 1,043 & t.,713 & 2,088 & 15,288 & 1,361 & 1,876 & 1383 & 1,410 & 1,410 \\
\hline Local twist funds & 1,082 & 1,574 & 1,786 & 2,696 & 2,377 & 1,856 & 1,806 & 1,120 & 1,120 \\
\hline Inwesment income & 5,061 & 8,679 & 2,806 & 2,663 & 3,205 & 13,906 & 6.711 & 3,700 & 3,700 \\
\hline Granis & 443,017 & 37,452 & 33,172 & 29,981 & 21,993 & 37,062 & 21,307 & 34,636 & 34,636 \\
\hline Cument gرanls & 72,843 & 26,161 & 26,098 & 26,435 & 18,624 & 19,298 & 19,128 & 20,342 & $20,3+2$ \\
\hline US. Compact & 62,107 & 18,623 & 18,856 & 19,220 & 11,570 & 11,640 & 11,701 & 11,827 & 11,827 \\
\hline U.S. nus-Canpact & 10,431 & 7,239 & 3,012 & 6,626 & 6,420 & 6,829 & 6,748 & 7,302 & 7,302 \\
\hline Other souniry & 305 & 299 & 230 & 589 & 634 & 829 & 679 & 1,213 & 1,213 \\
\hline Capilal gran's & 70,174 & 11,291 & 7,074 & 3,546 & 3,369 & 12,764 & 2,179 & 14,294 & 14,254 \\
\hline U.S. Compart & 64,360 & 4,900 & $3,500=$ & 2,000 & 2,000 & 2,100 & 2,000 & 2,000 & 2,000 \\
\hline U.S. nor-Curnpact & 5,814 & 6,391 & 3,574 & 1,546 & 1,369 & 569 & 179 & 3,894 & 3,894 \\
\hline Other cortutry & 0 & ] & 0 & 0 & 0 & 10,195 & 0 & $8,40: 0$ & 8,400 \\
\hline Total exptandinuts & 65,251 & 75,148 & 76,542 & 54,617 & 71,678 & 84,493 & 77,202 & $79,69:$ & 79,691 \\
\hline Curent expendinure & 56,722 & 58,145 & 58,252 & 54761 & 63,689 & 71,767 & 63,080 & 59,417 & 59,417 \\
\hline Wages and salsrica & 23,203 & 25,820 & 27,777 & 27,355 & 28,381 & 29,275 & 29,863 & 30,358 & 30,358 \\
\hline Phuchases of goods and services & 23,627 & 19,896 & 25,298 & 22,982 & 27,256 & 30,414 & 25,360 & 24,327 & 24,327 \\
\hline Interest payments & 83 & 0 & 0 & 0 & o & D & 700 & 700 & 700 \\
\hline Subsities and other currend transfers & 9,899 & 32,429 & 5,177 & 4,424 & B,052 & 12,078 & 7,157 & 4,032 & 4,032 \\
\hline Public entemprises & 5,543 & 7,889 & 3,037 & 1,964 & 1,337 & 3,149 & 3,287 & 1,662 & 5,662 \\
\hline Other & 4,266 & 4,540 & 2,140 & 2,460 & 6,715 & 8,929 & 3,870 & 2,370 & 2,370 \\
\hline Cafpilal expenditure & 8,529 & 17,003 & 18,250 & 9,856 & 7,989 & 12,726 & 14,122 & 20,274 & 20,274 \\
\hline Emors and nmurisions $3 /$ & $-2,560$ & 1,993 & 2,220 & $-4,252$ & 3,875 & 4,843 & $-2,770$ & 0 & 0 \\
\hline Overall balance & 97,276 & $-6,616$ & $-16,285$ & 2,437 & $-16,786$ & $-4,667$ & $-1 B, 479$ & $-9,633$ & $-4,458$ \\
\hline Financing & $.97,276$ & 6,616 & 16,285 & $-2,437$ & 16,786 & 4,667 & 18,479 & 9,633 & $4,45 \pi$ \\
\hline Wet long-tenn borrowing & $-4,590$ & $-3,000$ & $-3,4 B 0$ & $-3,600$ & $-4,067$ & 18,566 & 0 & 0 & 0 \\
\hline New borrowigg & 0 & 0 & 0 & 0 & 0 & 20,000 & 0 & 0 & 0 \\
\hline Principal repayments & 4,560 & 3,000 & 3,400 & 3,600 & 4,067 & 1,434 & 0 & 0 & 0 \\
\hline Privatization rooe pis & 0 & 0 & 3,052 & 0 & 0 & 0 & 0 & 0 & \\
\hline Coutinenuy Reserve Fund & 0 & 0 & 0 & 0 & 0 & 0 & 0 & 0 & $-1,696$ \\
\hline \multirow[t]{2}{*}{ Other (-) equal increasing asseds 4 / } & $-92,776$ & 9,616 & 16,633 & 1,163 & 20,853 & $-13,899$ & 18,479 & 9,633 & 6,154 \\
\hline & \multicolumn{9}{|c|}{ (As a percert of fiseal year GDP) } \\
\hline Tolal revenue and gants & 178.8 & 63.4 & SE8 & 61.3 & 44.6 & 64.1 & 51.7 & 54.6 & 58.7 \\
\hline Domestic Eeverne & 25.9 & 27.7 & 22.2 & 35.5 & 25.4 & 36.7 & 33.1 & 27.6 & 31.7 \\
\hline Tax teventue & 14.5 & 14.9 & 150 & 16,4 & 16.5 & 19.6 & 21.2 & 19.7 & 23.7 \\
\hline Nandax revenuse & 9.4 & 128 & 7.2 & 19.2 & 8.8 & 17.1 & 11.9 & 8.0 & 8.0 \\
\hline Of which ; Hestentent iscalle & 5.5 & 83 & 2.5 & 2.3 & 2.8 & 11.9 & 5.5 & 2.9 & 2.9 \\
\hline Granls & 154.9 & 39.7 & 29.6 & 25.8 & 19.2 & 27.4 & 17.6 & 27.0 & 27.0 \\
\hline Gurrent grants & 78.9 & 24.9 & 23.3 & 2.7 & 16.3 & 16.5 & 25.8 & 15.9 & 15.9 \\
\hline Gapital grants & 76.0 & 10.8 & 6.3 & 3.9 & 2.9 & 10.9 & 1.8 & $11 . \mathrm{L}$ & 11.1 \\
\hline Total expensitisa & 70.7 & 71.6 & G.B.4 & 55.6 & 62.6 & 72.2 & 63.6 & 62.2 & 62.2 \\
\hline Current expendinure & 61.4 & 53.4 & 32.0 & $\$ 7.1$ & 55.7 & 61.3 & 52.0 & 463 & 46.3 \\
\hline Capital expenditinc & 9.2 & 16.2 & 16.3 & 8.5 & 7.0 & 10.9 & 11.6 & 15.8 & 15.8 \\
\hline Overall balsusce & 205.4 & -6.3 & -14.5 & 2.1 & -14.7 & -4.0 & -15.2 & -7.5 & -3.5 \\
\hline Overall balsnse, exchuding grents & -49.6 & $-42,9$ & -44.2 & -23.7 & -33.9 & 31.7 & -32.8 & -34.5 & -30.5 \\
\hline \multicolumn{10}{|l|}{ Mermorandwrt icens: } \\
\hline CHP (fiscal yeer) Sy & 92,309 & 104,962 & 111,960 & 116,293 & 114,444 & 117,025 & 121,396 & 128,203 & 128,203 \\
\hline \multicolumn{10}{|l|}{ Direct fin mesed projects not included above } \\
\hline Congand rosd pruject 6/ & $\ldots$ & $\ldots$ & $\ldots$ & $\ldots$ & 5,000 & 20,000 & 28,571 & 28,571 & 28,571 \\
\hline Koror-Babeldagb (KB) tridge $6 J$ & $\ldots$ & $\ldots$ & $\ldots$ & $\ldots$ & $\ldots$ & 9,269 & 12,359 & 3,090 & 3,090 \\
\hline New Airpunt Project $6 j$ & $\ldots$ & $\ldots$ & $\ldots$ & $\ldots$ & $\ldots$ & $\cdots$ & $\ldots$ & 2,333 & 2,333 \\
\hline
\end{tabular}

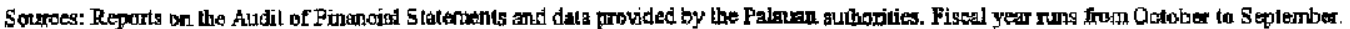

I/ At the time the budget was pagged, Congress ako, separalely, reduced "sin taxes", reducing revenue by $\$ 1.2$ milion.

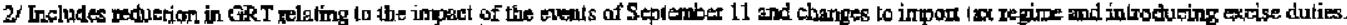

3/ Repoesents monies to be rejmbursed (from reimbursahle prants), changes in accounts payablefreceivable, and other urvientiffed iterns.

4, This is the thange in governtert assets (NTFA).

5 Caleulated using simple quexterly interpoletion.

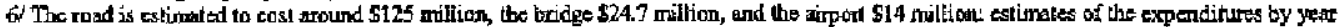

arze reporied. 
Table 8. Republic of Palau: U.S. Grants, 1994/95-2008/09

(L thousazds of U.S. dollars; end of the proriod)

\begin{tabular}{|c|c|c|c|c|c|c|c|c|c|c|c|c|c|c|c|}
\hline & $1994 / 95$ & $1995 / 96$ & $1996 / 97$ & $1997 / 98$ & $1998 / 99$ & $1999 / 00$ & $2000 / 01$ & $2001 / 02$ & $2002 / 01$ & $2003 / 04$ & $2004 / 05$ & $2005 / 06$ & $2006 / 07$ & $2007 / 08$ & $2008 / 09$ \\
\hline $\begin{array}{l}\text { Total Compact aid } \\
\text { of which: }\end{array}$ & 246,807 & 25,013 & 123,996 & 23,010 & 15,510 & 15,730 & 15,941 & 16,217 & 16,523 & 16,828 & 15,554 & 15,772 & 15,990 & 16,207 & 16,425 \\
\hline Total direct payments & 192,467 & 23,523 & 26,356 & 21,220 & 13,570 & 13,640 & 13,701 & 13,827 & 13,983 & 14,138 & 12,714 & 12,782 & 12,850 & 12,917 & 12,985 \\
\hline Operations & 14,948 & 12,781 & 12,781 & 12,781 & 7,781 & 7,851 & 7,781 & 7,781 & $7,78:$ & 7,781 & 6,781 & 6,781 & 6,781 & 6,781 & 6,781 \\
\hline Inflaticn adjustment & 6,279 & 5,842 & 6,075 & 6,439 & 3,789 & 3,789 & 3,920 & 4,046 & 4,202 & 4,357 & 3,933 & 4,001 & 4,069 & 4,136 & 4,204 \\
\hline Energy. Sextion 2J1(b) & 28,000 & $\cdots$ & $\ldots$ & $\ldots$ & $\cdots$ & $\ldots$ & $\ldots$ & $\ldots$ & $\ldots$ & $\cdots$ & $\ldots$ & $\ldots$ & $\ldots$ & $\cdots$ & $\ldots$ \\
\hline Inttation adjustment & 12,880 & $\cdots$ & $\ldots$ & $\cdots$ & $\cdots$ & $\cdots$ & $\cdots$ & $\cdots$ & $\cdots$ & $\cdots$ & $\cdots$ & $\cdots$ & $\cdots$ & $\cdots$ & $\cdots$ \\
\hline Trust Pund, Section 211 (f) & 66,000 & $\cdots$ & 4,000 & $\ldots$ & $\ldots$ & $\cdots$ & $\cdots$ & $\cdots$ & $\cdots$ & $\cdots$ & $\cdots$ & .. & $\ldots$ & $\ldots$ & $\cdots$ \\
\hline Capital improvements & 36,000 & $\ldots$ & $\cdots$ & $\cdots$ & $\ldots$ & $\cdots$ & $\cdots$ & $\ldots$ & $\cdots$ & $\ldots$ & $\cdots$ & $\cdots$ & $\cdots$ & $\cdots$ & $\cdots$ \\
\hline Inflation adjustment & 16,560 & $\ldots$ & $\cdots$ & $\cdots$ & $\cdots$ & $\cdots$ & $\cdots$ & $\ldots$ & $\cdots$ & $\cdots$ & $\cdots$ & $\cdots$ & $\cdots$ & $\cdots$ & .. \\
\hline Military options & 5,500 & $\ldots$ & $\ldots$ & $\ldots$ & $\ldots$ & $\ldots$ & $\ldots$ & $\ldots$ & $\ldots$ & $\ldots$ & $\ldots$ & $\ldots$ & $\ldots$ & $\ldots$ & $\ldots$ \\
\hline Specjal program assistance & 6,300 & 4,900 & 3,500 & 2,000 & 2,000 & 2,000 & 2,000 & 2,000 & 2,000 & 2,000 & 2,000 & 2,000 & 2,000 & 2,000 & 2,000 \\
\hline Total federal services & 54,340 & 1,490 & 97,640 & 1,790 & 1,940 & 2,090 & 2,240 & 2,390 & 2,540 & 2,690 & 2,840 & 2,990 & 3,140 & 3,290 & 3,440 \\
\hline Road systom construction (in-kimd) & 53,000 & $\cdots$ & 96,000 & $\ldots$ & $\cdots$ & $\cdots$ & $\ldots$ & $\cdots$ & $\cdots$ & $\ldots$ & $\cdots$ & $\cdots$ & $\cdots$ & $\cdots$ & $\cdots$ \\
\hline Weather, postal, aviation seryices & 1,340 & 1,490 & 1,640 & 1,790 & 1,940 & 2,090 & 2,240 & 2,390 & 2,540 & 2,690 & 2,840 & 2,990 & 3,140 & 3,290 & 3,440 \\
\hline Othax U.S. assistance 1/ & 16,245 & 13,630 & 10,586 & 8,172 & 7,789 & 7,398 & 6,927 & 11,196 & 8,575 & 8,575 & 8,575 & 8.575 & 8,575 & 8,575 & 8,575 \\
\hline Total US. grants & 263,052 & 38,643 & 134,582 & 31,182 & 23,299 & 23,128 & 22,868 & 27,413 & 25,098 & 25,403 & 24,129 & 24,347 & 24,565 & 24,782 & 25,000 \\
\hline
\end{tabular}

Sources: Independent Auditor's Report on finencial statements; and datn provided by the Bureau of Program, Budget, and Management, Ministry of Administration.

V Other U.S. nssistance is based on the proposats nutmitted to each grantor agency. Baged on the Compact agreement, various programs wore to be phased out beginning fiscal year 1996 . Schatuled phasing gut is 25 pexcent rectuetion of grant authorization for each fiscal yeac. However, there are old and new programs for which tho Republic of Palau is eligible- excordingly, other U.S. assistance is forecast to cantinue, but at a reduced level from $2002 / 03$. 
Table 9. Republic of Palau: National Government Expenditure by Budget Category, 1994/95-1999/00

(In thousands of U.S. dollars)

\begin{tabular}{|c|c|c|c|c|c|c|}
\hline & $1994 / 95$ & $1995 / 96$ & $1996 / 97$ & $1997 / 98$ & $1998 / 99$ & $1999 / 00$ \\
\hline Office of the President & 1,251 & 985 & 1,408 & 1,645 & 1,879 & 1,942 \\
\hline Office of the Vice-President & 390 & 410 & 437 & 507 & 442 & 450 \\
\hline \multicolumn{7}{|l|}{ Ministries } \\
\hline State & 1,627 & 1,846 & 1,731 & 1,859 & 2,244 & 2,440 \\
\hline Adminiatration & 1,618 & 2,204 & 1,953 & 1,911 & 2,587 & 2,661 \\
\hline Health & 7,608 & 8,030 & 9,704 & 9,147 & 9,536 & 10,193 \\
\hline Ecrucation & 11,204 & 8,844 & 9,173 & 8,833 & 9,710 & 9,055 \\
\hline Community and Cultural Affairs & 1,010 & 726 & 654 & 815 & 748 & 785 \\
\hline Social Services & $\ldots$ & $\ldots$ & $\ldots$ & $\ldots$ & $\ldots$ & ... \\
\hline Justice & 2,308 & 2,458 & 2,973 & 2,970 & 3,870 & 4,366 \\
\hline Resources and Development & 4,736 & 3,931 & 4,830 & 5,534 & 7,719 & 9,161 \\
\hline Commerce and Trade & 810 & 914 & 1,559 & 1,753 & 1,386 & 1,475 \\
\hline Natural Resources & $\cdots$ & $\cdots$ & $\cdots$ & $\ldots$ & $\cdots$ & $\ldots$ \\
\hline Boards, Comm \& Authorities & 1,208 & 835 & 791 & 454 & 335 & 564 \\
\hline Office of the Public Auditor & 391 & 527 & 608 & 566 & 779 & 689 \\
\hline Office of the Special Prosecutor & 136 & 188 & 117 & 62 & 213 & 227 \\
\hline Olbiil Era Kelulau (Congress) & 3,470 & 3,261 & 3,651 & 3,384 & 3,394 & 3,606 \\
\hline Grants to State Governments & 3,268 & 1,747 & 4,682 & 4,612 & 4,514 & 4,850 \\
\hline Judiciary & 1,618 & 1,793 & 1,915 & 2,045 & 2,206 & 2,259 \\
\hline Other $1 /$ & 4,260 & 7,018 & 6,890 & 5,204 & 4,074 & 4,966 \\
\hline Capital expenditures & 8,529 & 17,003 & 18,290 & 9,856 & 7,988 & 12,726 \\
\hline Interest payments & $\ldots$ & $\ldots$ & $\ldots$ & $\ldots$ & $\ldots$ & $\ldots$ \\
\hline Operating transfers $2 /$ & 9,809 & 12,429 & 5,176 & 3,460 & 8,052 & 12,078 \\
\hline Public enterprises & 5,543 & 7,889 & 3,036 & 1,000 & 1,337 & 3,149 \\
\hline Other $3 /$ & 4,266 & 4,540 & 2,140 & 2,460 & 6,715 & 8,929 \\
\hline Total & 65,251 & 75,148 & 76,542 & 64,617 & 71,678 & 84,493 \\
\hline
\end{tabular}

Sources: Reports on the Audit of Financial Statements for fiscal years 1992/93-1997/98 (1997/98 data are preliminary); and data provided by the Bureau of Program, Budget, and Management, MOA.

1/ Other expenditures include other programs from General Fund expenditures, Special Revenue Fund expenditures, CIP management fees, and prior year appropriations.

2/ Includes subsidies and other transfers for eurrent operations.

3/ Other major public entities receiving transfers are: Palau Community College PCC Board of Trustees, COM Board of Regents, Civil Service Pension Plan, and National Development Bank. 
Table 10. Republic of Palau: Operating Accounts of the State Governments, 1992/93-1998/99 (In thousands of U.S. dollars; end of period)

\begin{tabular}{|c|c|c|c|c|c|c|c|}
\hline & $1992 / 93$ & $1993 / 94$ & $1994 / 95$ & $1995 / 96$ & $\begin{array}{l}1996 / 97 \\
1 /\end{array}$ & $\begin{array}{l}1997 / 98 \\
2 /\end{array}$ & $\begin{array}{l}1998 / 99 \\
3 l\end{array}$ \\
\hline \multicolumn{8}{|l|}{ Reventes } \\
\hline National goversment grant & 2,704 & 2,612 & 1,303 & 4,960 & 3,092 & 1,346 & 1,546 \\
\hline Fishing right fees & 669 & 885 & 346 & 847 & 373 & 166 & 112 \\
\hline Interest income & 3 & 2 & 5 & 27 & 73 & 12 & 96 \\
\hline Other & 481 & 333 & 114 & 853 & 273 & 12 & 133 \\
\hline Total revenues & 3,856 & 3,832 & 1,768 & 6,688 & 3,811 & 1,535 & 1,791 \\
\hline \multicolumn{8}{|l|}{ Expenditures } \\
\hline \$alaries and wages & 650 & 654 & 334 & 1,451 & 1,312 & 455 & 552 \\
\hline Capital expenditure & 637 & 1,023 & 399 & 2,815 & 2,005 & 645 & 778 \\
\hline Other & 2,263 & 2,395 & 1,097 & 1,623 & 1,320 & 880 & 596 \\
\hline Total expenditures & 3,550 & $4,07 !$ & 1,830 & 5,889 & 4,637 & 1,980 & 1,926 \\
\hline Net collection (deficit) & 306 & -239 & -62 & 799 & -826 & -445 & -135 \\
\hline Account receivables floan repayment & $\ldots$ & 232 & $\ldots$ & -53 & -15 & $\ldots$ & $\ldots$ \\
\hline Fund balance (beginning of year) & 384 & 690 & 683 & 622 & 1,368 & 526 & 82 \\
\hline Fund balance (end of yeat) & 690 & 683 & 622 & 1,368 & 526 & 82 & -53 \\
\hline
\end{tabular}

Source: Data provided by the Office of the Public Auditor,

I/ A total of 2 States' Operations are not yet included in FY 1997.

2/ A total of 11 States' Operations are not yet included in FY 1998.

3/ A total of 12 States: Operations and the Fund balances are not yet included in FY 1999. 
Table 11. Republic of Palau: Financial Position of the Compact Section 211(f) Trust Fund, 1994/95-2000/01

(In thousands of U.S. dollars; end of period)

\begin{tabular}{|c|c|c|c|c|c|c|c|}
\hline & $1994 / 95$ & $1995 / 96 \mathrm{~d} /$ & $1996 / 972 /$ & $1997 / 983 /$ & $1998 / 99$ & $1999 / 00$ & $2000 / 01$ \\
\hline Total receipts & 71,034 & 6,961 & 28,862 & 17,600 & 19,621 & 21,472 & $-25,811$ \\
\hline Compact grants 4 & 66,000 & $\cdots$ & 4,000 & $\cdots$ & $\cdots$ & $\cdots$ & $\cdots$ \\
\hline $\begin{array}{l}\text { Investment gains and } \\
\text { Interest income }\end{array}$ & 5,034 & 6,961 & 24,862 & 17,600 & 19,621 & 21,472 & $-4,975$ \\
\hline [nvestment gains (losses) & 5,034 & $\ldots$ & 14,917 & 10,559 & 11,368 & $\ldots$ & $\ldots$ \\
\hline Inyestment ipterest inconse & $\cdots$ & 6,961 & 9,944 & 7,040 & 7,579 & $\cdots$ & $\cdots$ \\
\hline Total expendinures & 255 & 564 & 502 & 773 & 845 & 778 & 963 \\
\hline Investment fees & 255 & 564 & 502 & 773 & 845 & 778 & 963 \\
\hline Overall balance & 70,779 & 6,397 & 28,360 & 16,826 & 18,776 & 20,694 & $-26,774$ \\
\hline Fumd balance at year end & 70,779 & 77,176 & 105,536 & 122,362 & 141,139 & 161,832 & 135,039 \\
\hline
\end{tabular}

Sousces: Independent Auditor's Report on Financirl Straternen; and data provided by the Office of President and Mimistry of Adnuiristration.

1/ Invesment income for FY 1996 excluding unreatized losses \$731,594.

2/ For FY 1997, iovestment iacone includes testatement of investments at fair value is $\$ 11,019,473$.

3/ For FY 1998, inyestment izcome includes restatement of investments at fair value is $\$ 8,779,741$.

$4 /$ Covers operations of the Compact Section 21 1(1) Trust Fund, starting in 1994/95. 
Table 12. Republic of Palau: Financial Position of the Social Security Fund, 1993/94-2000/01 (In thousands of U.S. dollars)

\begin{tabular}{|c|c|c|c|c|c|c|c|c|}
\hline & $1993 / 94$ & $1994 / 95$ & $1995 / 96$ & $1996 / 97$ & $1997 / 98$ & $1998 / 99$ & $1999 / 00$ & $2000 / 01$ \\
\hline Revenues & 3,349 & 5,727 & 4,930 & 8,280 & 6,791 & 10,276 & 13,469 & $-1,342$ \\
\hline Contributions & 3,383 & 3,615 & 4,014 & 5,310 & 5,487 & 5,587 & 6,362 & 7,379 \\
\hline Government & 1,853 & 1,948 & 2,011 & 2,681 & 2,644 & $2,748 \ldots$ & 2,780 & 3,675 \\
\hline Private & 1,517 & 1,649 & 1,983 & 2,599 & 2,805 & 2,838 & 3,403 & 3,664 \\
\hline Penalties and interest & 13 & 18 & 20 & 30 & 38 & 1 & 179 & 40 \\
\hline Investrnent and other income & -34 & 2,112 & 916 & 2,970 & 1,304 & 4,689 & 7,107 & $-8,720$ \\
\hline Expenditures & 2,539 & 2,625 & $2,87 !$ & 3,105 & 3,354 & 3,713 & 4,215 & 4,295 \\
\hline Total benefit payout $1 /$ & 2,192 & 2,304 & 2,420 & 2,616 & 2,780 & 2,990 & $3,5,51$ & 3,908 \\
\hline Administrative fees $2 /$ & 347 & 321 & 451 & 489 & 574 & 723 & 564 & 387 \\
\hline Net coliection (deficit) & 810 & 3,102 & 2,059 & 5,175 & 3,437 & 6,563 & 9,254 & $-5,636$ \\
\hline Fund balance (end-year) & 9,477 & 12,579 & 14,638 & 19,813 & 23,250 & 29,813 & 39,067 & 33,431 \\
\hline
\end{tabular}

Sources: Annual andit reports; and data provided by the Palauan Social Security Office-

1/ Total benefit payout includes retirements, survivors, disability, and lump sum payments.

2/ Including administrative and investment management expenses and fees. 
Table 13. Republic of Palau: Financial Position of the

Civil Service Pension Fund, 1992/93-2000/01

(In thousands of U.S. dollars; end of period)

\begin{tabular}{|c|c|c|c|c|c|c|c|c|c|}
\hline & $1992 / 93$ & $1993 / 94$ & $1994 / 95$ & $1995 / 96$ & $1996 / 97$ & $1997 / 98$ & $1998 / 99$ & $1999 / 00$ & $\begin{array}{r}2000 / 01 \\
\text { June } \\
\end{array}$ \\
\hline & & & & & & & & & \\
\hline Revenues & 4,202 & 2,715 & 7,221 & 5,688 & 7,069 & 5,108 & 12,183 & 14,115 & 7,073 \\
\hline \multicolumn{10}{|l|}{ Contributions } \\
\hline Govemment employees & 2,228 & 2,708 & 2,851 & 3,125 & 3,285 & 3,309 & 3,438 & 3,596 & 1,040 \\
\hline Investment gains (losses) & 992 & -359 & 1,827 & 653 & 3,306 & 1,201 & 3,880 & 6,288 & 1,554 \\
\hline Investment interest incorne & 159 & 164 & 227 & 290 & 346 & 456 & 455 & 554 & 28 \\
\hline Other income & 672 & 52 & 86 & 120 & 132 & 142 & 110 & 177 & 76 \\
\hline Transfers from national government & 150 & 150 & 2,230 & 1,500 & & & 4,300 & 3,500 & 4,375 \\
\hline Expenditures & 2,032 & 1,840 & 2,305 & 2,536 & 3,025 & 3,116 & 3,488 & 4,328 & $1,2,99$ \\
\hline Tota] benefit payout $y$ & 1,416 & 1,557 & 1,980 & 2,078 & 2,545 & 2,703 & 3,008 & 3,819 & 1,252 \\
\hline Administrative fees $2 /$ & 616 & 283 & 325 & 458 & 480 & 413 & 480 & 509 & 46 \\
\hline Net collection (deficit) & 2,170 & 875 & 4,915 & 3,152 & 4,044 & 1,991 & 8,695 & 9,787 & 5,774 \\
\hline Fund balance (end-year) & 7,422 & 8,297 & 13,212 & 16,364 & 20,408 & 22,399 & 31,094 & 40,881 & 46.655 \\
\hline
\end{tabular}

Sources: Independent Auditors Report on financial statements; and data ptovided by the Palan Civi] Service Pension Plan Authority.

1/ Inchuding lump sum benefits, refunds, and disability benefits.

2/ Including investment management expenses and fees. 
Table 14. Republic of Palau: Operating Accounts of the Major Public Corporations, 1994/95-1999/00

(In thousands of U. S. dollars; end of period)

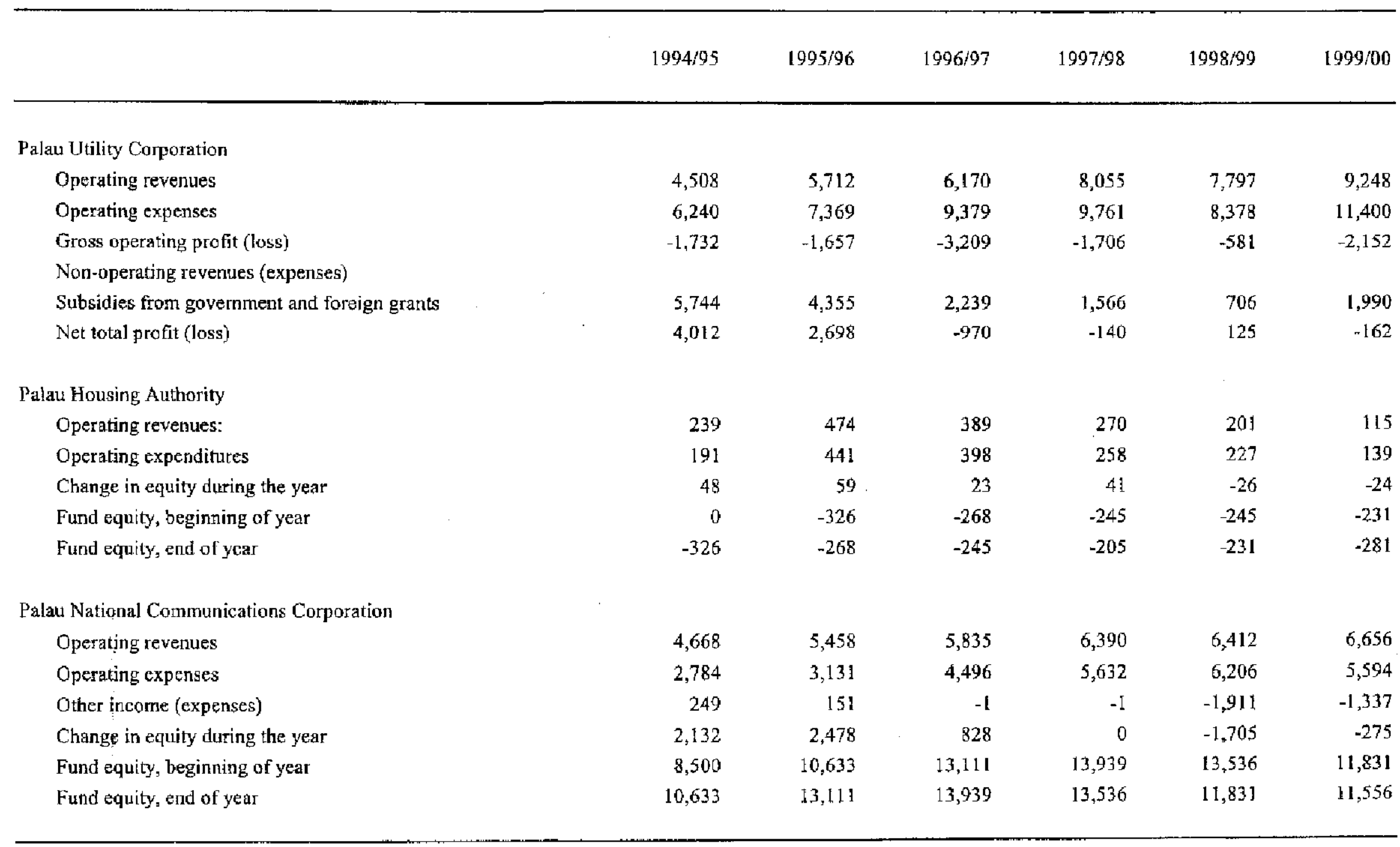

Sources: Independent Auditor's Report on Financial Statements; and data provided by the Palau Public Utilities Corporation, Paluan Housing Authority, and Palau National Communications Corporation. 
Table 15. Republic of Palau: Summary of Tax Structure

\begin{tabular}{|c|c|c|c|}
\hline Type of Tax & Nature of Tax & Exemptions and Deductfons & Rate Structure \\
\hline Wages and salaries tax. & $\begin{array}{l}\text { The wages and salaries tax is payable on the gross ineome } \\
\text { from wages and salaries of all individuals who work in the } \\
\text { Republic of Pajat. This includes Palauans, U.S. citizens, } \\
\text { and other expatriates who work under contracts. } \\
\text { The wages and salaries tax is payable to the National } \\
\text { Treasury within } 30 \text { days after making disbursement of wages } \\
\text { and salaries to the ermployes. } \\
\text { This is applicabie to all citizons and nonkitizens. U.S. } \\
\text { embassy personnel are not stibject to the tax. }\end{array}$ & Thete is an antual exemption of $\$ 2,000$. & $\begin{array}{l}6 \text { percent ( } \$(1-\$ 8,000) \text {. } \\
12 \text { percent over } \$ 8,000 \text {. }\end{array}$ \\
\hline Gross revenue tax. & $\begin{array}{l}\text { Business taxes are payable on gross receipts and are } \\
\text { applicable to sole ownerships, partnerships, and } \\
\text { corporations. } \\
\text { The gross revenue tax is payable on ar before the 30th day } \\
\text { following the close of each quarter. }\end{array}$ & $\begin{array}{l}100 \text { percent of wages ank salaries of citizens and } 50 \text { percent of } \\
\text { wages and salaries of nencitizens are allowable deductions. }\end{array}$ & $\begin{array}{l}4 \text { percent on the total } \\
\text { after allowable } \\
\text { deductions. }\end{array}$ \\
\hline Net income tax. & Financial institutions. & 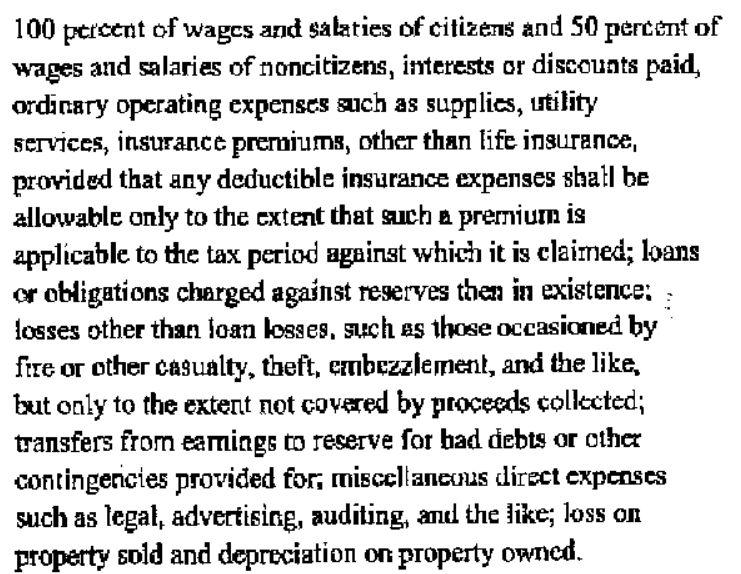 & 4 percent net incotne. \\
\hline
\end{tabular}


Table 15. Republic of Palau: Summary of Tax Structure

The nel income tax is payable on or before the 30th day

following the close of each quarter.

Inrmort tax

Every person who itriports products into the Republic of Patal for commercial purposes shall pay import texes.

Cigarettes.

Tobasco products, ather than cigareties.

Perfumery, cosmetics, including cologne and other toilet waters, anticles of perfumery, and all preparations to the hair and skin, except soap, toothpaste, shampoo, and the like,

lipsticks, pomades, powders, and other toilet preparations sot having thedicinal properties.

Carbonated soft drinks.

Beer.

Liquor

Wine.

Wine coolers.

Liquitd fuel.

Vehicles.

All other imported products.
Medicines, medical supplies, foodsauff for human

consumption, products for govemurent and fot personal

use are eximpt, except for vehicles.

$\$ 0.50$ per 20 sticks.

150 percent ad valorem.

25 percent ad valorem.

$\$ 0.10$ per la oz.

$\$ 0.03$ per az.

$\$ 0.30$ per $0 z$.

$\$ 0.20$ per oz.

$\$ 0,05$ per 02

$\$ 0.05$ per gal

5 percent ad valorem + $\$ 250.00$ per vehicle.

3 percent ad valorem. 
Table 15. Republic of Palau: Summary of Tax Structure

\begin{tabular}{|c|c|c|c|}
\hline Type of Tax & Nature of Tax & Exemptions and Deductions & Rate Structure \\
\hline Hotel Mfotel room tax. & $\begin{array}{l}\text { Every hotel and motel business is required to collect room } \\
\text { tax from guests and holl in trust and pay over to the } \\
\text { National Treasury. } \\
\text { The room tax is payable on or before the } 15 \text { th of every month. }\end{array}$ & & $\begin{array}{l}10 \text { percent of net roosn } \\
\text { charge. }\end{array}$ \\
\hline Amusement device tax. & $\begin{array}{l}\text { Every person who, at any time during the tax year, owns a coin- } \\
\text { activated amusement device for business shall pay an } \\
\text { amusement device tax. } \\
\text { Tax is payable within } 30 \text { days of its purchase or on or before } \\
\text { the } 31 \text { st day of Jamuary. }\end{array}$ & & $\$ 200.00$ per device. \\
\hline Travelers head tax. & $\begin{array}{l}\text { Every person departing from the Repubiic of Palat whether } \\
\text { by aircreft or by vessel shall pay a departure tax. }\end{array}$ & $\begin{array}{l}\text { Palauan stidents, children under the age of } 3 \text { and shasters, } \\
\text { pilots atd otber crewmembers of aircrafts or vessels are } \\
\text { exempt. }\end{array}$ & $\$ 20.00$ per person. \\
\hline Road use tax. & $\begin{array}{l}\text { Every person who owns a motor vehicle shall pay an annual } \\
\text { road use tax. Road use tax is based on motor vehicle } \\
\text { weight. } \\
\text { Tax is payable at titee of registration. }\end{array}$ & $\begin{array}{l}\text { National government and public corporations owned motor } \\
\text { velaicles are excopt. }\end{array}$ & $\begin{array}{l}\$ 50.00(0-2,000 \text { lbs. }) \\
\$ 75.00(2,000-4,000 \text { lbs. }) \\
\$ 150.00 \text { over } 4,000 \text { lbs. }\end{array}$ \\
\hline Forejgn water vessel tax. & $\begin{array}{l}\text { Every nonresidenteowned water vessel entering the Republic } \\
\text { of Palau shall be assessed and levied a tax. A nonresident- } \\
\text { owned water vessel present in the Republic of Palau for more } \\
\text { than one year shall be assessed and levied an annual tax. }\end{array}$ & U.S. military and common camier-owned vessels are exempt. & $\begin{array}{l}\$ 50.00 \text { per entry. } \\
\$ 250.00 \text { annual tax. }\end{array}$ \\
\hline Fish export tax. & $\begin{array}{l}\text { Every person exporting atty species of tuna or billfish in any } \\
\text { form for comrtercial purposes shall pay tax. }\end{array}$ & & $\$ 0.25$ per $\mathrm{kg}$. \\
\hline Vessei cabin tax. & $\begin{array}{l}\text { A tax levied against paying passengers taking overnight } \\
\text { cabin accommodalions on ships or water vessels owned or } \\
\text { operated by persons or business entities licensed to do } \\
\text { business in the Republic of Palau. }\end{array}$ & , & $\begin{array}{l}\text { 10 percent of eabin } \\
\text { charge or } \$ 10.00 \text { per } \\
\text { day or fraction thereof } \\
\text { whichever is greater. }\end{array}$ \\
\hline
\end{tabular}

Source: Ministry of Adrainistration 
Table 16. Republic of Palau: Operating Accounts of the National Development Bank of Palau, 1992/93-2000/01

(In thousands of U. S. dollars; end of period)

\begin{tabular}{|c|c|c|c|c|c|c|c|c|c|}
\hline & $1992 / 93$ & 1993/94 & $1994 / 95$ & $1995 / 96$ & $1996 / 97$ & $1997 / 98$ & $1997 / 99$ & $1999 / 00$ & $2000 / 01 \mathrm{~V}$ \\
\hline Revenues & 424 & 535 & 2,675 & 1,875 & 872 & 820 & 727 & 2,970 & 1,069 \\
\hline Interest & $\ldots$ & $\ldots$ & $\ldots$ & $\ldots$ & $\ldots$ & $\ldots$ & 629 & 564 & 737 \\
\hline Loan fees & 304 & 370 & 397 & 547 & 746 & 770 & 20 & 61 & 92 \\
\hline Others & 11 & 20 & 58 & 52 & 126 & 50 & 78 & 195 & 240 \\
\hline Transfers from national government $2 /$ & 58 & 95 & 219 & 276 & $\ldots$ & $\ldots$ & $\ldots$ & 2,150 & $\ldots$ \\
\hline Contributions from other countries & so & 50 & 2,000 & 1,000 & $\ldots$ & $\cdots$ & $\cdots$ & $\ldots$ & $\cdots$ \\
\hline Expenditures & 255 & 435 & 493 & 570 & 602 & 256 & 571 & 572 & 645 \\
\hline Wages and salaries & 103 & 117 & 107 & 138 & 136 & 123 & 1.48 & 158 & 210 \\
\hline Depreciation & 11 & 13 & 23 & 19 & 16 & 13 & 15 & 35 & 33 \\
\hline Interest & 32 & 33 & 36 & 17 & $\ldots$ & 5 & $\ldots$ & $\ldots$ & $\ldots$ \\
\hline Others & 110 & 272 & 327 & 395 & 450 & 115 & 408 & 379 & 402 \\
\hline Net income (tosses) & 169 & 100 & 2,182 & 1,305 & 270 & 564 & 156 & 2,398 & 424 \\
\hline Fund equity, beginning of year $3 /$ & 836 & 1,004 & 1,104 & 4,401 & 6,176 & 6,446 & 6,572 & 6,728 & 9,904 \\
\hline Fund equity, end of year & 1,005 & 1,104 & 3,286 & 5,706 & 6,446 & 7,010 & 6,728 & 9,126 & 10,328 \\
\hline
\end{tabular}

Sources: Independent Auditor's Report on Financial Statements; and data provided by the Palau National Development Bank (PNDB).

1/ Unaudited figures for FY2001.

$2 /$ Capital transfers the amount of $\$ 150,000$ for $\mathrm{Y} 2 \mathrm{~K}$ upgrading project and $\$ 2$ million for the first-time home-owner program from the government.

3/ Adjustment of fund equity for FY2001. 
Table 17. Republic of Palau: Assets and Liabilities of the National Development Bank of Palau, 1993/94-2000/01

(In thousands of U.S. dollars; end of period)

\begin{tabular}{|c|c|c|c|c|c|c|c|c|}
\hline & $1993 / 94$ & 1994/95 & $1995 / 96$ & $1996 / 97$ & $1997 / 98$ & $1998 / 99$ & $1999 / 00$ & $2000 / 01 \mathrm{I} /$ \\
\hline \multicolumn{9}{|l|}{ Assets } \\
\hline Cash. & 707 & 1,775 & 1,146 & 33 & 113 & 919 & 3,583 & 448 \\
\hline Time certificates of deposit & 100 & 500 & 600 & 606 & 1,339 & 1,413 & 1,084 & 4,313 \\
\hline Loans & 2,487 & 2,721 & 4,356 & 5,728 & 5,049 & 4,181 & 4,007 & 5,397 \\
\hline Fixed assets & 59 & 52 & 36 & 25 & 33 & 16 & 133 & 100 \\
\hline Other $2 /$ & 31 & 50 & 38 & 33 & 46 & 210 & 1,097 & $\pi$ \\
\hline Total assets & 3,384 & 5,098 & 6,176 & 6,425 & 6,580 & 6,739 & 9,904 & 10,329 \\
\hline \multicolumn{9}{|l|}{ Liabilitieș } \\
\hline Accounts payable $3 /$ & 28 & 18 & 23 & 1 & 8 & 10 & 23 & 25 \\
\hline Bonds payable & 253 & $\ldots$ & $\ldots$ & $\ldots$ & $\ldots$ & $\ldots$ & $\ldots$ & $\ldots$ \\
\hline Loans payable & 885 & 680 & 407 & 407 & $\ldots$ & $\ldots$ & $\ldots$ & \\
\hline Bank capital $4 i$ & 2,218 & 4,400 & 5,746 & 6,016 & 6,572 & 6,729 & 9,881 & 10,305 \\
\hline Total liabilities & 3,384 & 5,098 & 6,176 & 6,424 & 6,580 & 6,739 & 9,904 & 10,330 \\
\hline
\end{tabular}

Sources: Independent Auditor's Report on Financial Statement; and data provided by the Palau National Development Bank (PNDB).

1/ Figures from 1993/94-1999/00 are audited, 2000/01 figures are unaudited.

2/ Includes other receivables, inventory, prepaid experses, and receivable from Repubic of Palau.

3/Includes accrued expenses.

4/ Includes contributed capital and retained eamings. 
Table 18. Republic of Palau: Credit Allocation by the National Development Bank of Palau, 1993-2001

(In U.S. dollars)

\begin{tabular}{|c|c|c|c|c|c|c|c|c|c|}
\hline & 1993 & 1994 & 1995 & 1996 & 1997 & 1998 & 1999 & 2000 & 2001 \\
\hline Agriculture & 23,377 & 47,346 & 54,586 & 65,000 & 45,000 & 7,000 & $\ldots$ & 15,000 & 15,000 \\
\hline Fisheries & 270,936 & 239,374 & 201,608 & 359,000 & 164,000 & 16,000 & $\ldots$ & $\ldots$ & 16,882 \\
\hline Tourism & 867,315 & $1,259,143$ & $1,257,773$ & 348,000 & 265,000 & $\ldots$ & $\ldots$ & $\ldots$ & $\cdots$ \\
\hline Forestry & 181 & $\cdots$ & $\cdots$ & $\ldots$ & $\ldots$ & $\ldots$ & $\ldots$ & $\ldots$ & $\cdots$ \\
\hline Small business & 1,763 & 1,739 & $\cdots$ & 48,271 & $\ldots$ & $\ldots$ & $\cdots$ & $\cdots$ & $\ldots$ \\
\hline Manufacturing & $1,640,543$ & $1,353,788$ & $1,789,561$ & $2,469,000$ & $1,685,000$ & 70,000 & $\ldots$ & 488,651 & $1,134,984$ \\
\hline Conmerce and construction & $\ldots$ & $\ldots$ & $\ldots$ & $\ldots$ & $\ldots$ & $\ldots$ & $\ldots$ & $2,378,217$ & $1,881,138$ \\
\hline Họusing & $2,804,115$ & $2,901,390$ & $3,303,528$ & $3,289,271$ & $2,159,000$ & 93,000 & $\ldots$ & $2,881,868$ & $3,048,004$ \\
\hline Total loans & $2,804,115$ & $2,901,390$ & $3,303,528$ & $3,289,271$ & $2,159,000$ & 93,000 & $\ldots$ & $5,763,736$ & $6,096,008$ \\
\hline
\end{tabular}

Source: Data provided by the Palau National Development Bank (PNDB). 
Table 19. Republic of Palau: Imports by Product Category, 1994-2001 1/

(In thousand of U.S. dollars; F.O.B.)

\begin{tabular}{|c|c|c|c|c|c|c|c|c|c|}
\hline & 1994 & 1995 & 1996 & $\$ 997$ & 1998 & 19992 & 2000 & FYo0 & FYo1 \\
\hline Food and live animals & 6,647 & 9,164 & 9,317 & 10,987 & 8,462 & 10,446 & 14,213 & 14,650 & 14,534 \\
\hline Beverages and tobacico & 3,816 & 5,002 & 5,428 & 6,165 & 5,590 & 5,588 & 8,721 & 8,702 & 7,954 \\
\hline Crude materials, inedible except fuels & 33 & 187 & 118 & 199 & 172 & 821 & 1,968 & 1,858 & 1,840 \\
\hline Mineral fuels, lubricant, and related minerals & 19,882 & 15,057 & 20,886 & 8,341 & 14,761 & 11,036 & 16,428 & 20,093 & 9,930 \\
\hline Animal and vegetable oils, fats, and waxes & 112 & 234 & 204 & 268 & 235 & 188 & 273 & 248 & 247 \\
\hline Chemicals and related products. & 1,147 & 2,306 & 1,949 & 2,818 & 2,396 & 5,165 & 7,838 & 7,187 & 7,134 \\
\hline Manufactured goods & 3,546 & 4,765 & 4,930 & 5,713 & 5,090 & 14,490 & 24,989 & 25,223 & 18,203 \\
\hline Machinery and transport equipment & 5,936 & 13,246 & 23,846 & 17,599 & 18,045 & 18,977 & 34,242 & 32,350 & 23,179 \\
\hline Miscellaneous manufactured articles & 7,100 & 12,567 & 12,758 & 17,148 & 11,037 & $\$ 1,127$ & 15,312 & 16,816 & 12,744 \\
\hline Canmodities not classified eisewhere & 363 & 193 & 199 & 51 & 147 & $\cdots$ & $\ldots$ & $\cdots$ & $\cdots$ \\
\hline Total & 48,582 & 62,719 & 79,636 & 69,289 & 65,875 & 77,838 & 123,984 & 127,127 & 95,765 \\
\hline \multicolumn{10}{|l|}{ Memorandum items: } \\
\hline \multicolumn{10}{|l|}{ Duty exempt ituports $3 /$} \\
\hline Aid projects & $\ldots$ & $\cdots$ & $\ldots$ & $\cdots$ & $\cdots$ & 8,416 & 15,604 & 3,529 & $\cdots$ \\
\hline Diplomatic concession & $\ldots$ & $\ldots$ & $\ldots$ & $\ldots$ & $\ldots$ & 322 & 14 & 29 & $\ldots$ \\
\hline Food sturf & $\ldots$ & $\ldots$ & $\ldots$ & $\ldots$ & $\ldots$ & 1,215 & 122 & 613 & $\ldots$ \\
\hline Goverment use or tor pupose of trade & $\cdots$ & $\cdots$ & $\ldots$ & $\ldots$ & 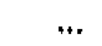 & 16,865 & 17,419 & 8,567 & $\ldots$ \\
\hline Mextioine/medical supplies & $\ldots$ & $\ldots$ & $\ldots$ & $\ldots$ & $\ldots$ & 734 & 586 & 577 & $\ldots$ \\
\hline Personal baggage & $\ldots$ & $\ldots$ & $\ldots$ & $\ldots$ & $\ldots$ & 617 & 422 & 675 & $\ldots$ \\
\hline Re-inport of tenuporary export & $\ldots$ & $\ldots$ & $\ldots$ & $\ldots$ & $\ldots$ & 203 & 560 & 94 & $\ldots$ \\
\hline Temparary import without transferral of & & & & & & & & & \\
\hline ownership & $\ldots$ & $\ldots$ & $\ldots$ & $\ldots$ & $\ldots$ & 24 & 3,225 & 94 & $\ldots$ \\
\hline
\end{tabular}

Sources: Data provided by the Customs Office, Ministry of Administration, and Ministry of Conmerce and Trade.

1/On a calendar year basis until 2000 .

2/ Data for 1999 are only for the last nine months due to adoption of Harmonized System in April 1999.

3/ Duty exernpt inports are in calendar years for 1999, 2000, and 2001. 
Table 20. Republic of Palau: Imports by Country or Territory of Origin, 1996-2001 l/

(Is thousands of U.S. dollars, f.o.b.)

\begin{tabular}{|c|c|c|c|c|c|c|}
\hline & 1996 & 1997 & $\begin{array}{l}1999 \\
2 / 3 /\end{array}$ & 2000 & FY $1999 / 00$ & FY $2000 / 01$ \\
\hline United States & 27,010 & 27,872 & 28,690 & 40,704 & 41,552 & 37,611 \\
\hline Singapore & 23,412 & 9,047 & 11,948 & 8,727 & 12,195 & 7,343 \\
\hline Guam & 12,473 & 12,223 & 8,381 & 17,472 & 17,033 & 13,379 \\
\hline Japan & 9,051 & 9,348 & 11,949 & 19,104 & 21,996 & 9,814 \\
\hline Taiwan Province of China & 2,391 & 3,465 & 5,370 & 8,012 & 8,751 & 5,091 \\
\hline Australia & 1,463 & 994 & 1,094 & 1,739 & 2,005 & 1,047 \\
\hline Hong Kong SAR & 1,070 & 1,245 & 634 & 5,585 & 4,434 & 3,484 \\
\hline Philippines & 1,053 & 1,221 & 2,297 & 3,374 & 4,215 & $2,6] 7$ \\
\hline Korea & 570 & 517 & 2,021 & 8,626 & 6,852 & 6,155 \\
\hline Saipan & 440 & 690 & $\ldots$ & $\cdots$ & $\cdots$ & $\cdots$ \\
\hline New Zealeand & 238 & 590 & 49 & 145 & 141 & 38 \\
\hline Micronesia, Federated States of & 189 & $\ldots$ & 79 & 110 & 118 & 389 \\
\hline China & 42 & 1,685 & 892 & 887 & 824 & 2,546 \\
\hline Malaysia & 37 & .. & 576 & 135 & 648 & 90 \\
\hline Indonesia & 9 & $\cdots$ & 786 & 2,231 & 2,850 & 367 \\
\hline Thailand & $\ldots$ & $\begin{array}{l}\cdots \\
\cdots\end{array}$ & 1,296 & 200 & 177 & 151 \\
\hline Pakistan & $\cdots$ & $\begin{array}{l}\cdots \\
\cdots\end{array}$ & 1.143 & 198 & 198 & $\ldots$ \\
\hline Other countries and territories; & 188 & 391 & 633 & 6,735 & 3,137 & 5,644 \\
\hline Total & 79,636 & 69,289 & 77,838 & 123,984 & 127,127 & 95,765 \\
\hline
\end{tabular}

Sources: Data provided by the Customs Office, Ministry of Administration, and Ministry of Commerce and Trade.

1/ On a calendar year basis until 2000.

2/ Data not available in 1998.

3/ Data for 1999 are only for the last wine months due to the introduction of new customs system in April 1999. 
Table 21. Republic of Palau: National Government Debt and Debt Service, 1992/93-2000/01

(In thousands of U.S. dollars)

\begin{tabular}{|c|c|c|c|c|c|c|c|c|c|}
\hline & $1992 / 93$ & $1993 / 94$ & $1994 / 95$ & $1995 / 96$ & $1996 / 97$ & $1997 / 98$ & $1998 / 99$ & $1999 / 00$ & $2000 / 01$ \\
\hline $\begin{array}{l}\text { Gross external debt } \\
\text { ICBC debt service }\end{array}$ & $67,429 U$ & $20,000 \mathrm{l} /$ & 15,500 & 12,500 & 9,100 & 5,500 & 1,433 & 20,000 & 20,000 \\
\hline \multicolumn{10}{|l|}{ Debt service } \\
\hline Principal 2f & 0 & 0 & 4,500 & 3,000 & 3,400 & 3,600 & 4,067 & 1,433 & $\cdots$ \\
\hline Interest $2 /$ & 0 & 0 & 0 & 0 & 0 & 0 & 0 & 0 & 700 \\
\hline
\end{tabular}

Sources: Independent Auditor's Report on Financial Statements; and data provided by the Ministry of Adniaistration.

1/ Totat external debt outstanding (related to the construction of IPSECO power plant), including payments arrears.

2/ In June 1993, an agreement was reached with the guarantor banks for the settienent of the outstancing FSECO debt, by which there would be a debt zelief and only $\$ 20$ million would be paid to the guarantor banks over the period 1994/95-1999/2000 without any interest payment. 
Table 22. Republic of Palau: Financial Holdings of the Central Government, 1992/93-2000/01

(In thousands of U.S. dollars; end of period)

\begin{tabular}{|c|c|c|c|c|c|c|c|c|c|}
\hline & $1992 / 93$ & $1993 / 94$ & $1994 / 95$ & $1995 / 96$ & $1996 / 97$ & $1997 / 98$ & $1998 / 99$ & $1999 / 00$ & $2000 / 01$ \\
\hline \multicolumn{10}{|l|}{ Forteigo assets $1 /$} \\
\hline Deposits with foreign banks & $\ldots$ & $\cdots$ & 96,173 & 83,953 & 76,086 & 64,241 & 64,628 & 45,313 & 40,102 \\
\hline \multicolumn{10}{|l|}{ Domestic assets $2 /$} \\
\hline Deposits with domestic banks & 854 & 474 & 622 & 2,300 & 4,715 & 17,580 & 2,377 & 32,369 & 3,882 \\
\hline Fiduciary funds $3 /$ & $\ldots$ & $\ldots$ & 70,779 & 77,176 & 105,536 & 122,362 & 141,139 & 161,832 & 135,039 \\
\hline Total financial holdings & 854 & 474 & 167,574 & 163,429 & 186,337 & 204,183 & 208,144 & 239,514 & 179,023 \\
\hline
\end{tabular}

Source: Data provided by the Palauan anthorities.

1/ Deposits with all foreign banks, including those in the United States.

2/ Deposits with local banks.

3/ Refer only to Compact Section 2 I (f) Trust Fund, excluding the Civil Service Rension Trust and Social Security Retirement Fund. 
Table 23. Republic of Palau: Selected Social Indicators, 1995 and 2000

\begin{tabular}{|c|c|c|}
\hline & 1995 & 2000 \\
\hline GDP per capita (U.S. dollars) & 5,527 & 6,179 \\
\hline \multicolumn{3}{|l|}{ Area (sq. miles) } \\
\hline Eand & 18.8 & 188 \\
\hline Sea & 237,850 & 237,850 \\
\hline \multicolumn{3}{|l|}{ Demographic indicators (2000) } \\
\hline Total population & 17,225 & 19,129 \\
\hline \multicolumn{3}{|l|}{ Population growth (percent per annum) } \\
\hline $1986-90$ & 2.4 & $\cdots$ \\
\hline $1990-95$ & 2.6 & $\cdots$ \\
\hline 2000 & & 2.1 \\
\hline Crude birth rate (per 1,000 ) & 13.4 & 14.5 \\
\hline Crude death rate (per 1,000 ) & 7.0 & 6.5 \\
\hline Infant mortality (per 1,000 ) & 20.0 & 10.8 \\
\hline Labor force & 8,368 & 9,845 \\
\hline Employed & 7,780 & 9,621 \\
\hline Agriculture, fisheries, and mining & 724 & 215 \\
\hline Construction & 1,089 & 1,112 \\
\hline Manufacturing & 78 & 345 \\
\hline Transport, storage, communication, and other public utilities & 436 & 765 \\
\hline Wholesale, retail, restaurants, and hotels & 1,455 & 2,619 \\
\hline Finance, insurance, and real estate & 124 & 116 \\
\hline Other business, personal, community, and social services & 1,120 & 1,246 \\
\hline Public administration & 2,879 & 3,203 \\
\hline Unemployed & 588 & 224 \\
\hline \multicolumn{3}{|l|}{ Age structure (in percent) } \\
\hline $0-14$ & 28.1 & 23.9 \\
\hline $15-64$ & 66.2 & 70.7 \\
\hline 65 and over & 5.7 & 5.4 \\
\hline \multicolumn{3}{|l|}{ Public health and education } \\
\hline \multicolumn{3}{|l|}{ Education } \\
\hline \multicolumn{3}{|l|}{ Percent graduating } \\
\hline Primary & 97.0 & 97.0 \\
\hline Secondary & 65.0 & 78.0 \\
\hline College & 12.2 & 10.0 \\
\hline Student/teacher ratio (1998 and 2000) & 10.7 & 10.6 \\
\hline \multicolumn{3}{|l|}{ Health } \\
\hline Number of encounters at dispensary & 115 & 48 \\
\hline
\end{tabular}

Sources: 1995 and 2000 Census of Population and Honsing from the Office of Plaming and Statistics; and Social Security Office. 